\title{
Carbon dioxide dynamics from sediment, sediment-water interface and overlying water in the aquaculture shrimp ponds in subtropical estuaries, southeast China
}

\section{Article}

Accepted Version

Creative Commons: Attribution-Noncommercial-No Derivative Works 4.0

Yang, P., Lai, D. Y. F., Yang, H. and Tong, C. (2019) Carbon dioxide dynamics from sediment, sediment-water interface and overlying water in the aquaculture shrimp ponds in subtropical estuaries, southeast China. Journal of Environmental Management, 236. pp. 224-235. ISSN 0301-4797 doi: https://doi.org/10.1016/j.jenvman.2019.01.088 Available at https://centaur.reading.ac.uk/82359/

It is advisable to refer to the publisher's version if you intend to cite from the work. See Guidance on citing.

To link to this article DOI: http://dx.doi.org/10.1016/j.jenvman.2019.01.088

Publisher: Elsevier

All outputs in CentAUR are protected by Intellectual Property Rights law, including copyright law. Copyright and IPR is retained by the creators or other copyright holders. Terms and conditions for use of this material are defined in the End User Agreement. 


\section{www.reading.ac.uk/centaur}

\section{CentAUR}

Central Archive at the University of Reading

Reading's research outputs online 


\section{Carbon dioxide dynamics from sediment, sediment-water interface and}

2 overlying water in the aquaculture shrimp ponds in subtropical estuaries,

\section{Southeast China}

4 Ping Yang, ${ }^{1,2,3}$ Derrick Y F. Lai, ${ }^{4}$ Hong Yang, ${ }^{5,6,7}$ Chuan Tong ${ }^{1,2,3}$

$5 \quad{ }^{1}$ Key Laboratory of Humid Subtropical Eco-geographical Process of Ministry of Education, Fujian Normal

6 University, Fuzhou 350007, P.R. China

$7 \quad{ }^{2}$ School of Geographical Sciences, Fujian Normal University, Fuzhou 350007, P.R. China

$8{ }^{3}$ Research Centre of Wetlands in Subtropical Region, Fujian Normal University, Fuzhou 350007,

$9 \quad$ P.R. China

$10{ }^{4}$ Department of Geography and Resource Management, The Chinese University of Hong Kong, Shatin,

11 New Territories, Hong Kong SAR, China

$12{ }^{5}$ Collaborative Innovation Center of Atmospheric Environment and Equipment Technology, Jiangsu Key

13 Laboratory of Atmospheric Environment Monitoring and Pollution Control, School of Environmental

14 Science and Engineering, Nanjing University of Information Science \& Technology, 219 Ningliu Road,

15 Nanjing 210044, China

$16{ }^{6}$ College of Environmental Science and Engineering, Fujian Normal University, Fuzhou, 350007, China

$17{ }^{7}$ Department of Geography and Environmental Science, University of Reading, Whiteknights, Reading,

18 RG6 6AB, UK

19

20 *Correspondence to: Ping Yang

21 Telephone: 086-0591-87445659

22 Fax: 086-0591-83465397

23 Email: yangping528@sina.cn (P. Yang)

$24 * *$ Correspondence to: Chuan Tong

25 Telephone: 086-0591-87445659

26 Fax: 086-0591-83465397

27 Email: tongch@fjnu.edu.cn (C. Tong) 


\section{A B S T R A C T}

Aquaculture ponds can emit a large amount carbon dioxide $\left(\mathrm{CO}_{2}\right)$, with the consequence of exacerbating global climate change. Many studies about $\mathrm{CO}_{2}$ dynamics across the water-air interface, but $\mathrm{CO}_{2}$ in sediment and overlying water received relative less attention. In this study, $\mathrm{CO}_{2}$ concentration in sediment porewater, the diffusive $\mathrm{CO}_{2}$ fluxes across the sediment-water interface (SWI), and the $\mathrm{CO}_{2}$ production rates in the overlying water $\left(\mathrm{CO}_{2} \mathrm{WP}_{\mathrm{P}}\right)$ were determined in the shrimp ponds in the Min River Estuary (MRE) and Jiulong River Estuary (JRE), southeast China, to analyze the dynamics of $\mathrm{CO}_{2}$ among different growth stages of shrimps. Our results showed large variations in porewater $\mathrm{CO}_{2}$ concentrations, $\mathrm{CO}_{2}$ diffusive fluxes and $\mathrm{CO}_{2}$ wP rates among different growth stages, with markedly larger values in the middle stage of shrimp growth. The temporal variation of $\mathrm{CO}_{2}$ in both estuarine ponds followed closely the seasonal change of temperature. The internal $\mathrm{CO}_{2}$ production $\left(\mathrm{CO}_{2} \mathrm{IP}\right)$ in these ponds was dominated by sediments. A significantly larger mean porewater $\mathrm{CO}_{2}$ concentrations, diffusive fluxes and production rate were observed in the MRE ponds than in the JRE ponds, which could be attributed to the lower water salinity and a larger source of carbon substrates in the former estuary. Considering a total surface area of $6.63 \times 10^{3} \mathrm{~km}^{2}$ across the mariculture ponds in subtropical estuaries, it is estimated conservatively that approximately 100 Gigagram $(\mathrm{Gg})$ of dissolved organic carbon and $190 \mathrm{Gg}$ of dissolved inorganic carbon were transported annually from the mariculture ponds into China's coastal areas. Because of the substantial supply of dissolved carbon, the adjacent coastal waters receiving effluent discharge from the mariculture ponds could become "hotspots" of $\mathrm{CO}_{2}$ emissions. Our results highlight the role of aquaculture pond as a major $\mathrm{CO}_{2}$ source in China's coastal areas, and effective actions are needed to alleviate the greenhouse gases (GHGs) emissions in these areas.

Keywords: Carbon dioxide; Sediment-water interface; Production rates; Mariculture ponds; Subtropical estuary 


\section{$54 \quad$ Nomenclature table}

\begin{tabular}{|c|c|c|c|}
\hline Nomenclature & Abbreviations & Nomenclature & Abbreviations \\
\hline Greenhouse gases & GHGs & $\begin{array}{l}\mathrm{CO}_{2} \text { production rates in the } \\
\text { overlying water }\end{array}$ & $\mathrm{CO}_{2}$ WP \\
\hline Gigagram & $\mathrm{Gg}$ & Internal $\mathrm{CO}_{2}$ production & $\mathrm{CO}_{2 \_ \text {IP }}$ \\
\hline Dissolved organic carbon & DOC & $\begin{array}{l}\mathrm{CO}_{2} \text { production at the sediment } \\
\text { by microbial mineralization }\end{array}$ & $\mathrm{CO}_{2 \_S P}$ \\
\hline Dissolved inorganic carbon & DIC & $\begin{array}{l}\mathrm{CO}_{2} \text { production in the water } \\
\text { column by photochemical } \\
\text { mineralization }\end{array}$ & $\mathrm{CO}_{2 \_P P}$ \\
\hline Total carbon & $\mathrm{TC}$ & $\begin{array}{l}\mathrm{CO}_{2} \text { production in the water } \\
\text { column by and heterotrophic } \\
\text { respiration of shrimps }\end{array}$ & $\mathrm{CO}_{2 \_\mathrm{SR}}$ \\
\hline Chlorophyll $a$ & Chl- $a$ & Two-way analysis of variance & ANOVA \\
\hline Sediment-water interface & SWI & $\begin{array}{l}\text { Repeated measures analysis of } \\
\text { variance }\end{array}$ & RMANOVA \\
\hline Min River Estuary & MRE & Principal component analysis & PCA \\
\hline Jiulong River Estuary & JRE & & \\
\hline
\end{tabular}

55 


\section{Introduction}

The increasing worldwide concerns over global climate change and its effects on ecosystem and human society call for a better understanding of the magnitude of greenhouse gas (GHGs) emissions (Tong et al., 2010; Yang et al., 2011). Carbon dioxide $\left(\mathrm{CO}_{2}\right)$ is one of the most potent GHGs, accouting for nearly $60 \%$ of the overall radiative forcing in the air (Mosier, 1998; Myhre et al., 2013). Global atmospheric $\mathrm{CO}_{2}$ concentration has increased from $280 \mathrm{ppm}$ in 1750 to $405 \mathrm{ppm}$ in 2017, exceeding the pre-industrial levels by about $40 \%$ (World Meteorological Organization, 2018). Aquatic ecosystems (e.g. lakes, reservoirs, rivers, and others) are known to be important sources of atmospheric $\mathrm{CO}_{2}$. Earlier estimates indicate that inland freshwaters could emit in the order of $1.4 \mathrm{Pg} \mathrm{C}_{\text {year }}{ }^{-1}$ in the form of $\mathrm{CO}_{2}$ (Tranvik et al., 2009), equivalent to approximately 55\% of terrestrial carbon sink (Raymond et al., 2013; Tangen et al., 2016). Yet, accurate estimates of regional and global $\mathrm{CO}_{2}$ budgets remains challenging because of large uncertainty regarding aquatic $\mathrm{CO}_{2}$ emissions due to insufficient measurements. Shallow waters, including aquaculture ponds, have recently been highlighted as key hotspots for $\mathrm{CO}_{2}$ emissions (Holgerson and Raymond, 2016; Yang et al., 2018b). Quantifying the potential sources of various aquatic ecosystems has become one of the top priorities for improving the prediction of future $\mathrm{CO}_{2}$ emission.

In response to the urgent need of climate change mitigation, there has been an increasing number of studies in recent years to explains on the impacts of aquaculture systems on carbon cycle (e.g. Chen et al., 2015; Chen et al., 2016; Sidik and Lovelock, 2013; Yang et al., 2018b). However, the majority of these studies only focused on $\mathrm{CO}_{2}$ fluxes across the water-air interface of aquaculture ponds, with little attention on the $\mathrm{CO}_{2}$ fluxes across the sediment-water interface (SWI) (Xiong et al., 2017). $\mathrm{CO}_{2}$ production can takes place either in anaerobic sediments or in aerobic water columns (Gruca-Rokosz et al., 2011; Xing et al., 2005); unfortunately, there is a lack of research on $\mathrm{CO}_{2}$ production rates in the aerobic water column of aquaculture ponds. It is important to note that $\mathrm{CO}_{2}$ fluxes across the water-air interface are not necessarily equivalent to the $\mathrm{CO}_{2}$ fluxes across the SWI, due to the fact the actual proportion of $\mathrm{CO}_{2}$ emitted to the atmosphere is also influenced by microbiological processes in water column (Gruca-Rokosz and Tomaszek, 2015; Xing et al., 2006; Yang et al., 2008). Therefore, studying the $\mathrm{CO}_{2}$ dynamics across the SWI and quantifying the $\mathrm{CO}_{2}$ production rates in the overlying water is crucial to improve our understanding of the overall carbon balance of aquaculture ponds and its resulting impacts on global warming.

According to the recent statistics, approximately $90 \%$ of the global aquaculture production occurs in Asia (FAO, 2014). In particular, China has world's largest mariculture industry (Gu et al., 2017a, 2017b), with a total mariculture pond area and production of $2.57 \times 10^{4} \mathrm{~km}^{2}$ and $2.30 \times 10^{9} \mathrm{~kg}$ in 2015 , which representing approximately $30 \%$ of the world total of pond area and $60 \%$ of the world total of aquaculture production (Chen et al., 2016). Land-based aquaculture is the one of dominant approaches of mariculture shrimp production (FAO, 2014). Mariculture ponds are generally semi-artificial ecosystems, with a large amount of organic matter 
supply from daily input of feeds (Chen et al., 2015; Yang et al., 2018a). The decomposition of organic matter from residual feeds and feces in these ponds can stimulate $\mathrm{CO}_{2}$ production and emissions (Burford et al., 2003; Chen et al., 2016). Aquaculture ponds are inherently heterogeneous over spatiotemporal scales due to the changes in topographic features, environmental conditions, and tidal fluctuations, leading to large uncertainties in the calculation of $\mathrm{CO}_{2}$ production and emissions. Unfortunately, the spatiotemporal variability of $\mathrm{CO}_{2}$ production and emissions from mariculture ponds are nearly unknown, which could cause biases in the estimation of the contribution of mariculture activities to radiative forcing and global. In the current research, we aim to fill these knowledge gaps by analyzing the $\mathrm{CO}_{2}$ dynamics in aquaculture ponds between two subtropical estuaries in Fujian Province, which is one of the main distribution centers of shrimp produce in China.

\section{Materials and methods}

\subsection{Study area description}

This study was conducted in the Min River Estuary (MRE) and Jiulong River Estuary (JRE) located in southeastern China (Fig. 1; Yang et al., 2018). The MRE has a typically subtropical monsoon climate, warm and wet in summer, with annual precipitation of $1,350 \mathrm{~mm}$ and annual mean temperature of $19.6^{\circ} \mathrm{C}$ (Tong et al., 2010). The JRE is in the subtropical oceanic climate zone. The mean annual rainfall is $1,371 \mathrm{~mm}$ and annual air temperature is $21.0^{\circ} \mathrm{C}$ (Wang et al., 2013). Both estuaries receive a greater amount of precipitation during the period between May and September owing to the southeast monsoon. Tides in both estuaries are semi-diurnal. The surface wetland soil is submerged for approximately $7 \mathrm{~h}$ during a $24 \mathrm{~h}$ cycle. The mean salinities of tidal water in MRE and JRE are approximately $4.2 \pm 2.5 \mathrm{ppt}$ (Tong et al., 2012) and 21.3 \pm 2.9 ppt, respectively. Shrimp pond, one of the main landscapes in the estuarine zones, was mostly created by removing marsh vegetation.

\subsection{Shrimp pond system and management}

Because the optimal water temperatures to culture shrimp (Litopenaeus vannamei) are $22-35^{\circ} \mathrm{C}$, only one crop of shrimp could be produced annually at MRE and JRE (Yang et al., 2017a). The shrimp production cycle began in the second half of May and lasted for six months. Before the shrimp production, the ponds were filled with salt water pumped from an adjacent estuary. To prevent shrimp's predators and competitors, the water was also passed through a 2-mm mesh bag (Guerrero-Galván et al., 1999; Yang et al., 2017a). Freshwater was added into the ponds in rainy days. After shrimp harvesting, water was discharged from the pond spillways. During the culture period, water levels in shrimp ponds ranged 1.1-1.5 m and $1.3-1.8 \mathrm{~m}$ in MRE and JRE, respectively.

Shrimps were fed with artificial feeds containing $42 \%$ crude protein (Yuehai ${ }^{\mathrm{TM}}$, China) in the morning (07:00) and afternoon (16:00) by direct application on the boat. According to water quality, pond management practices, and shrimp weight, the shrimp growth cycle was divided into three stages: initial, middle, and final stages (Yang et al., 2017a). Three to five 1,500-W paddlewheel aerators were operated four times daily (07:00-09:00, 12:00-14:00, 18:00-20:00, and 00:00-03:00) in the ponds. Detailed information on the shrimp pond systems and management 
practices was reported in a previous study (Yang et al., 2017a). To analyze $\mathrm{CO}_{2}$ dynamics in the culture period, water and sediment were sampled from three representative shrimp ponds at Shanyutan Wetland in MRE and the Humao Island in JRE, respectively (Fig. 1). Basic details of the selected mariculture ponds in the two estuaries are presented in Table $\mathrm{S} 1$.

\subsection{Collection and analysis of water and sediment samples}

\subsubsection{Collection and analysis of water samples}

Field sampling campaigns were performed in June, August, and October 2015 which represented three culture stages (initial, middle, and final). Sampling was performed on different but consecutive days (less than six days between the two estuaries) in any sampling campaign. Overlying water samples were collecteded from three sites in each pond. Overlying water was sampled at approximately $5 \mathrm{~cm}$ above the bottom sediments using a 5-L Niskin water sampler. Water samples were stored in an ice box, and transported to the laboratory within $4 \mathrm{~h}$ for incubation and measurement of water quality parameters within one week (Yang et al., 2017a). A portion of the water samples was filtered through a $0.45 \mu \mathrm{m}$ cellulose acetate filter (Biotrans $^{\mathrm{TM}}$ nylon membranes). The filtrates were subsequently analyzed for dissolved organic carbon (DOC) and dissolved inorganic carbon (DIC) using a Shimadzu total organic carbon analyzer (TOC-V, Yang et al., 2017a). Chl- $a$ concentrations in water samples were determined using a UV-visible spectrophotometer (Shimadzu UV-2450, Japan) following the methods of Jeffrey and Humphrey (1975) and Yang et al. (2017a). In addition, during each sampling campaign, the overlying water temperature and $\mathrm{pH}$ were determined using a $\mathrm{pH} / \mathrm{mV} /$ Temp system (IQ150, IQ Scientific Instruments, USA), the salinity was measured using a salinity meter (Eutech Instruments-Salt6, USA) and DO was measured using a multi-parameter water quality meter (HORIBA, Japan).

\subsubsection{Collection and analysis of sediment samples}

Four intact sediment cores were sampled at each of the triplicate sites in each pond using a surface-operated coring device (Core-60, Austria). The device is composed of a core cylinder, a plexiglas tube (30 cm length, $6 \mathrm{~cm}$ internal diameter) and a one-way check valve which can preserve the integrity of $15 \mathrm{~cm}$ sediment and $15 \mathrm{~cm}$ overlying water (Yang et al., 2017a). The cores were sealed, stored vertically in an ice box, and transported to the laboratory within $4 \mathrm{~h}$. In the laboratory, the four replicate sediment cores collected at each site were used separately for incubation experiments, and the measurement of sediment physicochemical properties, dissolved $\mathrm{CO}_{2}$ concentrations, and physicochemical variables of sediment porewater. Sediment temperature were measured using a handheld $\mathrm{pH} / \mathrm{mV} /$ temperature meter (IQ150, IQ Scienti fic Instruments, USA). Sediment porosity $(\Phi)$ was calculated based on the water content of sediment determined by weight loss after drying at $105^{\circ} \mathrm{C}$ for $24 \mathrm{~h}$ (Zhang et al., 2013). Applying a soil-to-water ratio of 1:2.5 (w/v), sediment $\mathrm{pH}$ was determined using a $\mathrm{pH}$ meter (Orion 868, USA). After freeze drying, homogenization and grinding to fine power (Sun et al., 2013), sediment was analyzed for total carbon (TC) using an elemental analyzer (Elementar Vario MAX $\mathrm{CN}$, Germany). Porewater was extracted from the bulk sediment by centrifugation at 
5,000 rpm for $10 \mathrm{~min}$ (Cence® L550, De Vittor et al., 2012). The extracted porewater samples were divided into two portions. One portion of the porewater samples was filtered through $0.45 \mu \mathrm{m}$ pore size cellulose acetate filters (Biotrans ${ }^{\mathrm{TM}}$ nylon membranes) (De Vittor et al., 2012) and the filtrates were analyzed for DOC and DIC concentrations, while the other unfiltered portion was measured for salinity using an Eutech Instruments-Salt6 salinity meter.

To measure the dissolved $\mathrm{CO}_{2}$ concentrations in sediment porewater, $6 \mathrm{~cm}^{3}$ of sediment subsamples were collected in duplicate with $10 \mathrm{~mL}$ cut-off syringes and sealed in serum vials containing $24 \mathrm{~mL}$ of $\mathrm{CO}_{2}$-free water and $0.5 \mathrm{~mL}$ of saturated $\mathrm{HgCl}_{2}$ solution. The mixtures were shaken to achieve gas equilibrium between the slurry and the headspace (Dutta et al., 2015). Finally, the headspace $\mathrm{CO}_{2}$ concentration was analyzed using a gas chromatograph (GC-2010, Shimadzu, Kyoto, Japan). The $\mathrm{CO}_{2}$ concentration in porewater $\left(C, \mathrm{mg} \mathrm{CO}_{2} \mathrm{~L}^{-1}\right)$ was calculated using the following equation (Ding et al., 2010; Johnson et al., 1990):

$C=\left(C_{\mathrm{h}} / 22.4\right) \times\left[(\beta \times R \times T) / 22.4+\left(V_{\mathrm{h}} / V_{\mathrm{p}}\right)\right] \times(M / 1000)$

where $C_{\mathrm{h}}$ is the $\mathrm{CO}_{2}$ concentration in vial headspace $\left(\mathrm{mL} \mathrm{L}^{-1}\right) ; \beta$ is the Bunsen solubility coefficient for $\mathrm{CO}_{2}\left(\mathrm{~L} \mathrm{~L}^{-1}\right)$ (Wiesenburg and Guinasso, 1979); $R$ is the gas constant $(0.0814) ; T$ is the room temperature $\left({ }^{\circ} \mathrm{C}\right) ; M$ is molar mass of $\mathrm{CO}_{2}(\mathrm{mg}$ $\left.\mathrm{mol}^{-1}\right)$; and $V_{\mathrm{h}}$ and $V_{\mathrm{p}}$ are the volumes of vial headspace volume $(\mathrm{mL})$ and water sample $(\mathrm{mL})$, respectively.

\subsection{Laboratory incubation for the determination of $\mathrm{CO}_{2}$ production and flux rates}

The $\mathrm{CO}_{2}$ production rates in the overlying water and $\mathrm{CO}_{2}$ fluxes across the SWI were determined by ex situ incubation. The incubation device (Fig. S1) was constructed following the guide of Chen et al. (2014), Xiong et al. (2017), and Yang et al. (2017a). Intact core samples containing equal volumes of sediments and overlying water were transported to the laboratory within $4 \mathrm{~h}$ after collection and placed in incubation chambers for $2 \mathrm{~h}$ to re-establish the equilibrium conditions (Xiong et al., 2017). After reaching an equilibrium, the incubation chambers were carefully filled with overlying water using a rubber pipe (Fig. S1) (Yang et al., 2017a), with special attention being paid to maintain a sufficiently low water flow rate to avoid any disturbance of the sediment surface. After filling the incubation chambers with overlying water, the cores were sealed with a Teflon plunger equipped with inlet and outlet tubes (Fig. S1). The overlying water was continuously bubbled with air to simulate the in situ oxic conditions of water above the sediment (Mu et al., 2017), and overlying water were stirred during incubation. The chambers were then incubated in a temperature-regulated incubator device (QHZ-98A, China) for $9 \mathrm{~h}$ (Yang et al., 2017a). The incubation temperature was set to be the same as the field temperature (MRE: 22.5, 28.5, and $22.5{ }^{\circ} \mathrm{C}$ in June, August, and October, respectively; JRE: 25.5, 29.0, and $26.5{ }^{\circ} \mathrm{C}$ in June, August, and October, respectively). $60 \mathrm{~mL}$ of water samples were withdrawn from each chamber near the SWI using a $100 \mathrm{~mL}$ plastic syringe at $0 \mathrm{~h}, 3 \mathrm{~h}, 6 \mathrm{~h}$, and $9 \mathrm{~h}$ of the incubation period. Subsequently, water samples were transferred to headspace vials to determine dissolved $\mathrm{CO}_{2}$ concentrations using a gas chromatograph (Shimadzu GC-2010, 
Japan) based on the gas-stripping method (Zhang et al., 2010a). After each water sampling, the same volume of field-collected overlying water was introduced into the chamber (Fig. S1) to replace the sampled water and maintain the total volume of the water column in the incubation chamber. In addition, we incubated bottom water without any sediment under the same conditions in a separate chamber to estimate the $\mathrm{CO}_{2}$ production rate in bottom water.

Dissolved $\mathrm{CO}_{2}$ concentration in water samples was estimated by applying Henry's law and taking into account the dependence of gas solubility on water temperature and salinity (Lide and Frederikse, 1997; Wanninkhof et al., 1992). The $\mathrm{CO}_{2}$ flux across the sediment-water interface (SWI) $\left(\mathrm{mg} \mathrm{m} \mathrm{m}^{-2} \mathrm{~h}^{-1}\right)$, and $\mathrm{CO}_{2}$ production rate in bottom water $\left(\mathrm{CO}_{2}\right.$ wP, $\left.\mathrm{mg} \mathrm{m}^{-2} \mathrm{~h}^{-1}\right)$ were calculated based on the $\mathrm{CO}_{2}$ concentration changes in the water column over incubation time (Equation 2) (Xiong et al., 2017; Zheng et al., 2009):

$$
\mathrm{CO}_{2} \text { flux }\left(\text { or } \mathrm{CO}_{2}{ }_{-} \mathrm{wP}_{\mathrm{P}}\right)=\frac{d \mathrm{c}}{d \mathrm{t}} \times V \times S \times(M / 1000)
$$

where $\frac{d \mathrm{c}}{d \mathrm{t}}$ is the rate of change in $\mathrm{CO}_{2}$ concentrations in the overlying water (mmol $\left.\mathrm{L}^{-1} \mathrm{~h}^{-1}\right) ; V$ is the volume of overlying water in the incubation chamber (L); $S$ is the cross-sectional area of the sediment core $\left(\mathrm{m}^{2}\right)$; and $M$ is molar mass of $\mathrm{CO}_{2}(\mathrm{mg}$ $\mathrm{mol}^{-1}$ ). Positive values of $\mathrm{CO}_{2}$ fluxes indicate a net $\mathrm{CO}_{2}$ release from sediments into the water column, whereas negative values indicate a net $\mathrm{CO}_{2}$ uptake by sediments from the water column.

\subsection{Statistical analysis}

Two-way analysis of variance (ANOVA) was conducted to analyze the influences of estuaries and culture stages and the interaction between the two factors on sediment porewater $\mathrm{CO}_{2}$ concentrations, $\mathrm{CO}_{2}$ flux across the $\mathrm{SWI}$, and $\mathrm{CO}_{2}$ WP. Repeated measures analysis of variance (RMANOVA) was operated to examine the differences in environmental variables of shrimp ponds between these two estuaries during the study period, with the data collected in a given estuary over the three stages of shrimp growth being the repeated measures. Pearson correlation analysis was conducted to estimate the relationships (1) between porewater $\mathrm{CO}_{2}$ concentrations, $\mathrm{CO}_{2}$ wP, or $\mathrm{CO}_{2}$ flux and environmental variables, and (2) between $\mathrm{CO}_{2}$ fluxes and the gradient of $\mathrm{CO}_{2}$ concentrations in both sediment porewater and the overlying water. Principal component analysis (PCA) was also performed to analyze relationships among the $\mathrm{CO}_{2}$ production rates (or $\mathrm{CO}_{2}$ fluxes) and observed environmental parameters and to show their pattern at different aquaculture stages. A stepwise regression analysis was further used to screen the major influential environmental factors for the temporal variations of $\mathrm{CO}_{2}$ production rates in overlying water and $\mathrm{CO}_{2}$ fluxes across the SWI from different estuarine ponds. All statistical analyses were performed using the SPSS statistical software package (SPSS v 22.0, IBM, Armonk, NY, USA) and the statistical results at the level of 0.05 were considered as significance. The results were presented as average \pm 1 standard error. Statistical plots and conceptual diagrams were generated using OriginPro 7.5 


\section{Results and Discussion}

\subsection{Surface sediment, porewater, and overlying water characteristics}

The characteristics of surface sediments in the shrimp ponds of the two estuaries over the study period are shown in Fig. $2 \mathrm{a}-\mathrm{c}$. The minimum and maximum sediment temperatures were recorded at initial and middle stages, respectively. Significant differences in mean temperature were detected between the two estuaries at all three periods $(p<0.05)$ (Fig. 2a). Sediment porosity at MRE was significantly lower at the initial stage than middle and final stages $(p<0.05)$ (Fig. 2b), while at JRE, significantly higher porosity was observed during the middle stage $(p<0.05)$ (Fig. 2b). The average sediment porosity was significantly higher at JRE than MRE over the study period $(p<0.01)$. A similar seasonal trend was observed for sediment TC content in the shrimp ponds, with considerably smaller and larger results at initial and middle stages, respectively (Fig. 2c). Although the temporal patterns of sediment TC at MRE and JRE were very similar, significant differences in mean values were observed between the two estuaries in all three periods $(p<0.01)$ (Fig. $2 c)$. Meanwhile, the mean TC values found in our ponds were within the range of 1.08-5.43\% observed across 233 aquaculture ponds around the world (Boyd et al., 2010). The mean sediment $\mathrm{pH}$ values at ponds in MRE and JRE were $6.9 \pm 0.1$ and $6.3 \pm 0.1$, respectively. The seasonal changes of sediment $\mathrm{pH}$ at ponds in two estuaries followed the order of initial stage < final stage < middle stage.

The characteristics of sediment porewater in the shrimp ponds are shown in Fig. $2 \mathrm{~d}-\mathrm{f}$. The temporal patterns of porewater salinity were very similar in the two estuaries, with a generally decreasing trend over the study period (Fig. 2d). Due to a greater input of freshwater (e.g., terrestrial/estuarine groundwater, precipitation), JRE had significantly higher porewater salinity than MRE $(p<0.01)$. Porewater DOC concentration reached a minima and a maxima in October and August, respectively, while significant differences in mean DOC concentrations between the two estuaries were detected in both June and August $(p<0.01)$ (Fig. 2e). The lowest and highest porewater DIC concentrations were detected in June and August, respectively, with no significant differences between the two estuaries at all times $(p<0.05)$ (Fig. 2e). The variations in various environment variables in the overlying water during the shrimp growth cycle are shown in Fig. 2. The bottom water had $\mathrm{pH}$ values ranging 8.4-10.2 at MRE and 8.2-9.8 at JRE (Fig. 3a), with significant differences between estuaries at initial and final stages $(p<0.05)$, and significantly lower $\mathrm{pH}$ at middle stage $(p<0.05)$. DO concentrations in the pond water of both estuaries showed an increasing trend over time (Fig. 3b). The concentrations of DOC and DIC in JRE ponds increased with time, while those in MRE ponds were significantly higher during the middle stage ( $p<0.05$; Fig. $3 c$ and $3 d)$. The mean water DOC and DIC concentrations at MRE ponds were $12.6 \pm 0.3 \mathrm{mg} \mathrm{L}^{-1}$ and $21.9 \pm 1.2 \mathrm{mg} \mathrm{L}^{-1}$, respectively, which were significantly higher than those at JRE ponds $(6.7 \pm 0.4 \mathrm{mg}$ $\mathrm{L}^{-1}$ and $16.2 \pm 0.7 \mathrm{mg} \mathrm{L}^{-1}$, respectively, $p<0.01$ ).

\subsection{Porewater dissolved $\mathrm{CO}_{2}$ concentrations}

The concentrations of dissolved $\mathrm{CO}_{2}$ in the sediment porewater are shown in 
Fig. 4a. The mean porewater $\mathrm{CO}_{2}$ concentrations at MRE and JRE ponds during the study period were $4.9 \pm 0.6$ and $2.1 \pm 0.6 \mathrm{mg} \mathrm{L}^{-1}$, respectively, with a range of 4.4-6.0 and 0.9-3.1 mg L $\mathrm{mg}^{-1}$, respectively. The porewater $\mathrm{CO}_{2}$ concentrations at MRE and JRE demonstrated similar seasonal trends, with higher and lower values at the middle and final stages, respectively (Fig. $4 \mathrm{a}$ and Table 1). $\mathrm{CO}_{2}$ concentration shared the similar patterns with temperature and porewater DOC in sediments ( $p<0.05$ or $p<0.01$ ) (Fig. $2 \mathrm{a}$ and $2 \mathrm{e}$, and Table 2), indicating that temperature, organic matter, and their interactions were important factors influencing the variability of porewater $\mathrm{CO}_{2}$ concentrations in shrimp ponds. The $\mathrm{CO}_{2}$ in porewater was predominantly produced by the degradation of organic matter (Gruca-Rokosz and Tomaszek, 2015; Wollast, 1993). The presence of a large amount of organic matter would supply a large amount of substrates to microbes for the soil $\mathrm{C}$ mineralization (Kristensen et al., 2008; Yang et al., 2012), with the possible consequence of increase in porewater $\mathrm{CO}_{2}$ levels. Furthermore, a higher temperature could greatly enhance microbial decomposition of soil organic matter (Golovatskaya and Dyukarev, 2009; Lafleur et al., 2005), and thus the release of $\mathrm{CO}_{2}$ from sediments into the porewater. Our results suggested that the high sediment temperature and the large organic matter associated with the high bait feeding and intense metabolic activity of shrimps (Burford et al., 2003) would contribute to the elevated porewater $\mathrm{CO}_{2}$ concentrations observed in the middle stage compared to initial and final stages. The strong and negative correlations found between $\mathrm{pH}$ and porewater $\mathrm{CO}_{2}$ concentrations (Table 2) further suggested that the temporal variations in sediment porewater $\mathrm{CO}_{2}$ concentrations might partly depend on $\mathrm{pH}$ changes. Our results were in agreement with those of previous studies conducted in aquatic ecosystems (e.g. Crawford et al., 2013; Neal et al., 1998; Wallin et al., 2010), especially in shallow aquaculture ecosystems (Chen et al., 2016; Xiong et al., 2017).

Porewater $\mathrm{CO}_{2}$ concentrations varied significantly between MRE and JRE across these three shrimp growth stages $(p<0.001)$ (Table 1$)$, with generally high and very low values for MRE and JRE ponds, respectively (Fig. 4a). One possible reason for this spatial variations could be attributed to the differences in sediment TC contents and porewater DOC concentrations (Fig. 2c and 2e, and Table 1), which was in line with the earlier discussion of the effects of organic matter on sediment $\mathrm{CO}_{2}$ production. In the present study, MRE ponds had much lower porewater salinity than JRE ponds (Fig. 2d), which could be a result of freshwater dilution caused by the interactions between precipitation and surface runoff. Combining two estuaries together, porewater $\mathrm{CO}_{2}$ concentration were negatively correlated with porewater salinity $(r=0.54, p<0.01)$, indicating that salinity was another important factor influencing the porewater $\mathrm{CO}_{2}$ concentrations in the estuarine ponds. High salinity has been suggested to inhibit the activities of, or even bring harm to, microorganisms, which would subsequently reduce carbon mineralization rates and $\mathrm{CO}_{2}$ production (Hu et al., 2017).

\subsection{Production rates of $\mathrm{CO}_{2}$ in overlying water}

The culture of aquatic fauna in mariculture ponds is supported by daily supply of feeds (Chen et al., 2016). These ponds accumulate a large amount of organic 
carbon from residual feeds and feces (Burford et al., 2003; Chen et al., 2016), which supported significant $\mathrm{CO}_{2}$ production arising from the microbial decomposition of organic matter in the aerobic water column and subsequently the release of $\mathrm{CO}_{2}$ from aquaculture ponds into the atmosphere as shown by our data. Fig. 4b shows our laboratory incubation experiment results about the production rates of $\mathrm{CO}_{2}$ in the overlying water. There was a clear temporal variation of $\mathrm{CO}_{2}$ production rates in all the mariculture ponds during the study period $(p<0.001$, Table 1$)$. The $\mathrm{CO}_{2}$ production rates in MRE ponds ranged between 14.5 and $22.0 \mathrm{mg} \mathrm{m}^{-2} \mathrm{~h}^{-1}$, with significantly smaller values during the initia and final stages than middle stage ( $p<0.01$ ). The $\mathrm{CO}_{2}$ production rates in JRE ponds ranged $3.9-15.8 \mathrm{mg} \mathrm{m}^{-2} \mathrm{~h}^{-1}$, with significantly lower results at the initial stage $(p<0.01$, Fig. $4 \mathrm{~b})$. Chen et al. (2015) observed similar temporal patterns in grass carp Ctenopharyngodon idella polyculture ponds, and suggested that temperature, Chl- $a$ (Chlorophyll $a$ ) concentrations, and water temperature played a primary role in controlling $\mathrm{CO}_{2}$ production. Some studies also reported a considerable temporal variability in $\mathrm{CO}_{2}$ production rates in the freshwater environment and wetland sediments (e.g. Almeida et al., 2016; Vachon et al., 2016; Weyhenmeyer et al., 2015), which was mainly governed by seasonal variability in temperature and organic matter concentrations (Hu et al., 2017; Vachon et al., 2016). However, the results of our principal component analysis showed that the temporal variations in $\mathrm{CO}_{2}$ production rates were primarily related to different sets of environmental variable between sites (Fig. 5). In MRE ponds, the $\mathrm{CO}_{2}$ production rate was significantly related to DOC $(R=$ $0.84, p<0.01)$ and temperature $(R=0.72, p<0.01)$ (Fig. 5a), which together accounted for $76.1 \%$ of the variance in $\mathrm{CO}_{2}$ production rates (Table 3). In JRE ponds, however, the temporal patterns of overlying water $\mathrm{CO}_{2}$ production rates were mainly driven by salinity $(R=0.76, p<0.01)$ and DIC concentration $\left(R^{2}=0.72, p<0.01\right)$ (Fig. $5 b$ ), which together accounted for $68.7 \%$ of the variance in $\mathrm{CO}_{2}$ production (Table 3 ). Salinity was a significant factor affecting $\mathrm{CO}_{2}$ production in JRE but not MRE, which could be related to the much lower baseline salinity level and hence a greater sensitivity of microbial activities to salinity changes in the former estuary. In contrast, $\mathrm{CO}_{2}$ production in the more saline MRE ponds was more strongly controlled by the supply of organic substrates (e.g. DOC) for microbial mineralization.

The production rates of $\mathrm{CO}_{2}$ in the overlying water also varied markedly between the two estuaries (Fig. 4b). The mean $\mathrm{CO}_{2}$ production rate in MRE was significantly higher than that in JRE ponds $\left(17.6 \pm 1.3 \mathrm{vs} .10 .6 \pm 1.3 \mathrm{mg} \mathrm{m}^{-2} \mathrm{~h}^{-1}\right.$, $p<0.001$, Table 1). The conversion of natural coastal wetlands to aquaculture ponds conceals or eliminates the spatial heterogeneity, topographic features, and hydrological characteristics of the habitats (Yang et al., 2017b). However, the magnitude of chemical parameters measured in the pond overlying water varied significantly between the two estuaries. In particular, significant differences in salinity, DOC, and DIC concentrations between MRE and JRE ponds were observed $(p<0.05$ or $p<0.01$ ) (Fig. 2 d, and Fig. 3c, 3d). The survival rate and the densities of shrimps and baits were the major factors affecting DOC and DIC concentrations in mariculture ponds (Yang et al., 2018a). Considering high density of shrimps, a large 
amount of bait was added into the ponds in MRE. However, the low survival rate of shrimps (MRE vs. JRE: 65\% vs 71\%) had resulted in a substantial accumulation of surplus baits, which would decompose and contribute to high DOC and DIC concentrations in the water column (Fig. 3c and Fig. 3d). In addition, the lower salinity in MRE arising from the greater amount of freshwater runoff could contribute to the enhanced $\mathrm{CO}_{2}$ production in the ponds (Fig. 4b). In contrast, the JRE ponds had a higher water salinity but a lower bait concentration as a result of a lower density and a higher survival rate of shrimps, which together led to both lower organic matter content and $\mathrm{CO}_{2}$ production rates as compared to MRE (Fig. 4b). Our results showed that local environmental conditions affecting the physico-chemical properties of shrimp pond water (e.g. organic matter, salinity, and others) were important driver causing the observed difference in $\mathrm{CO}_{2}$ production rates between ponds.

\subsection{Fluxes of $\mathrm{CO}_{2}$ across the sediment-water interface}

$\mathrm{CO}_{2}$ fluxes across the SWI are shown in Fig. 4c. The relationships between $\mathrm{CO}_{2}$ fluxes and the environmental variables are also shown in two separate PCA plots, which demonstrated the temporal patterns in MRE (Fig. 5c) and JRE ponds (Fig. 5d), respectively. The $\mathrm{CO}_{2}$ fluxes from ponds in MRE and JRE were high, ranging between 43.6 and $97.7 \mathrm{mg} \mathrm{m}^{-2} \mathrm{~h}^{-1}$ and between 20.2 and $99.9 \mathrm{mg} \mathrm{m}^{-2} \mathrm{~h}^{-1}$, respectively. Significant differences in mean $\mathrm{CO}_{2}$ fluxes were recorded among the three shrimp growth stages $(p<0.001$, Table 1$)$ and the highest values was detected in the middle stage (Fig. 4c). The temporal variations in pond $\mathrm{CO}_{2}$ fluxes between the two estuaries were influenced similarly by sediment temperature (MRE: $R^{2}=0.38, p<0.01$; JRE: $R^{2}=0.69, p<0.01$; also see Fig. 5 and Table 4) and sediment TC level (MRE: $R^{2}=0.17, \quad p<0.05$; JRE: $\left.R^{2}=0.31, p<0.01\right)$, implying that the importance of temperature for the mineralization of organic matter and $\mathrm{CO}_{2}$ fluxes across the SWI (Table 4 and Fig. 5). Xiong et al. (2017) also reported that an increase in temperature could stimulate soil microbial activities and carbon mineralization, resulting in an oversaturation of $\mathrm{CO}_{2}$ and hence a large release of $\mathrm{CO}_{2}$ from the sediments to the overlying water. Moreover, this study found that the temporal changes in $\mathrm{CO}_{2}$ fluxes across the SWI were similar to those of the gradient of $\mathrm{CO}_{2}$ concentrations between the porewater and overlying water over the study period (Fig. 6), indicating that the $\mathrm{CO}_{2}$ diffusive gradient could at least in part govern the variations in $\mathrm{CO}_{2}$ flux among the three stages of shrimp growth. Some recent studies further suggested that $L$. vanname $i$ in the aquaculture ponds could affect carbon transport and transformation in surface sediments because the depth of sediment bioturbation caused by this shrimp was up to $2 \mathrm{~cm}$ (Xiong et al., 2017; Zhong et al., 2015). The different intensities of bioturbation among the three shrimp growth stages might also contribute to the observed seasonal changes of $\mathrm{CO}_{2}$ fluxes across the SWI.

Over the study period, the mean $\mathrm{CO}_{2}$ flux across the SWI in the MRE ponds was $63.68 \pm 6.56 \mathrm{mg} \mathrm{m}^{-2} \mathrm{~h}^{-1}$, greater than that in the JRE ponds $\left(54.36 \pm 7.70 \mathrm{mg} \mathrm{m}^{-2}\right.$ $\mathrm{h}^{-1}$ ). The variation patterns of $\mathrm{CO}_{2}$ flux and porewater $\mathrm{CO}_{2}$ concentration were highly similar (Fig. 4a and 4c; $r^{2}=0.40, p<0.001$ ), which is consistent with that of previous findinds that high $\mathrm{GHG}$ emissions are associated with high porewater GHG 
concentrations (Tong et al., 2018; Xiang et al., 2015; Zhang et al., 2010b). The magnitude of $\mathrm{CO}_{2}$ fluxes from our estuarine ponds was also different from that of other aquatic ecosystems (Table 5). The average values and the range of $\mathrm{CO}_{2}$ fluxes observed in our shrimp pond systems were substantially larger than those reported in lakes (Casper et al., 2003; Liikanen et al., 2002; Ogrinc et al., 2002; Yang et al., 2015a) and reservoirs (Gruca-Rokosz et al., 2011; Gruca-Rokosz and Tomaszek, 2015). The $\mathrm{CO}_{2}$ fluxes across the SWI from the shrimp ponds in our two estuaries were also higher than those from the subtropical rivers or estuaries, such as the Mississippi River Estuary, USA (Morse and Rowe, 1999) and the Shanghai river network, China (Tan, 2014), but generally lower than those from the drainage ditches in the Netherlands (Schrier-Uijl et al., 2011) and the intertidal mudflats in Japan (Kikuchi, 1986). Meanwhile, the magnitude of $\mathrm{CO}_{2}$ fluxes in our study was similar to that in the freshwater aquaculture systems in China (Xiong et al., 2017), which suggested that the sediments of mariculture ponds could be potential "hotspots" of $\mathrm{CO}_{2}$ emissions, and the role of mariculture ponds should be taken into account when evaluating the $\mathrm{CO}_{2}$ balance of aquatic ecosystems.

The high $\mathrm{CO}_{2}$ fluxes across the SWI observed in our shrimp ponds were, to some extent, related to the large supply of organic matter. These mariculture ponds were often maintained through daily feed application to culture the target aquatic fauna (Chen et al., 2015, 2016). In fact, the feed utilization efficiency is unfortunately as low as 4.0-27.4\% (Chen et al., 2015; Molnar et al., 2013), so only a limited proportion of the feed inputs could be converted into fish biomass. Very likely majority of the added feeds would end up accumulating in the mariculture systems (Chen et al., 2015; Yang et al., 2017a), leading to the generation of a large amount of organic residues, mainly uneaten feeds, during mariculture production that in turn stimulate microbial decomposition and subsequently $\mathrm{CO}_{2}$ production and emission from mariculture ponds.

\subsection{Implications and future outlook for carbon biogeochemical cycling}

\subsubsection{Role of sediments in the internal $\mathrm{CO}_{2}$ production of shrimp ponds}

Decomposition or mineralization of organic matter plays a crucial role in the internal $\mathrm{CO}_{2}$ production in aquatic ecosystems (Müller et al., 2015; Vreča, 2003). According to Weyhenmeyer et al. (2015), the internal $\mathrm{CO}_{2}$ production $\left(\mathrm{CO}_{2} \mathrm{IP}\right)$ comprised of three different processes, namely $\mathrm{CO}_{2}$ production at the sediment by microbial mineralization $\left(\mathrm{CO}_{2} \mathrm{sP}\right), \mathrm{CO}_{2}$ production in the water column by microbial mineralization of DOC $\left(\mathrm{CO}_{2} \mathrm{WP}_{\mathrm{WP}}\right.$ ), and $\mathrm{CO}_{2}$ production in the water column by photochemical mineralization $\left(\mathrm{CO}_{2 \_\mathrm{PP}}\right)$. Numerous studies reported that $\mathrm{CO}_{2}$ WP often made the largest contribution to the internal $\mathrm{CO}_{2}$ production in the boreal lakes (e.g. Almeida et al., 2016; Brothers et al., 2012; Weyhenmeyer et al., 2015). Weyhenmeyer et al. (2015) reported that the median $\mathrm{CO}_{2}$ production rate in over 5,000 boreal lakes generally followed the order of $\mathrm{CO}_{2}$ wP $\left(221 \mathrm{mg} \mathrm{C} \mathrm{m}^{-2} \mathrm{~d}^{-1}\right)>$ $\mathrm{CO}_{2}$ SP $\left(47 \mathrm{mg} \mathrm{C} \mathrm{m}^{-2} \mathrm{~d}^{-1}\right)>\mathrm{CO}_{2}$ PP $\left(25.6 \mathrm{mg} \mathrm{C} \mathrm{m}^{-2} \mathrm{~d}^{-1}\right)$, with significantly higher

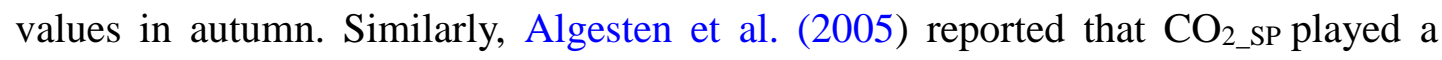
minor role in the production and emissions of $\mathrm{CO}_{2}$ in the boreal and subarctic lakes in the summer. In the present study, $\mathrm{CO}_{2}$ release fluxes across the SWI and $\mathrm{CO}_{2}$ WP 
in the shrimp ponds ranged between 20.2 and $99.9 \mathrm{mg} \mathrm{m}^{-2} \mathrm{~h}^{-1}$, and between 3.9 and $22.0 \mathrm{mg} \mathrm{m}^{-2} \mathrm{~h}^{-1}$, respectively. The mean $\mathrm{CO}_{2}$ release fluxes across the SWI in the two estuarine ponds was over 3.9 times larger than the $\mathrm{CO}_{2}$ wP rate $\left(58.9 \mathrm{vs} .14 .9 \mathrm{mg} \mathrm{m}^{-2}\right.$ $\mathrm{h}^{-1}, p<0.01$ ), which suggested that sediment $\mathrm{CO}_{2}$ production contributed substantially to the total production and emissions of $\mathrm{CO}_{2}$ in subtropical aquaculture ponds during the culture period. The relative larger contribution of $\mathrm{CO}_{2}$ SP to the $\mathrm{CO}_{2} \mathrm{IP}$ in subtropical shrimp ponds is different from that in the boreal and subarctic lakes. There were two possible mechanisms that could account for the considerable impacts of sediments on the $\mathrm{CO}_{2}$ balance in the current study. First, the pond sediment received a large quantity of organic carbon from residual feeds and feces (Chen et al., 2016; Yang et al., 2017a) that served as important substrates to microbes for decomposition and subsequent $\mathrm{CO}_{2}$ production. Second, the shallow water depth (an average of $1.5 \mathrm{~m}$ ) and the operation of paddlewheel aerators would effectively promote the diffusion of oxygen from the water into the sediment (Silva et al., 2013; Yang et al., 2017a), which in turn enhance aerobic respiration and the microbial decomposition of sediment organic matter.

\subsubsection{Impact of pond effluent on $\mathrm{CO}_{2}$ dynamics in receiving coastal waters}

In the end of aquaculture production, pond water is complete drained to discard the aquaculture wastewater and aerate the bottom sediments to prepare for the next production (Herbeck, et al., 2013; Yang et al., 2017a). During this management practice, large quantities of nutrient-enriched water would be transferred into the adjacent coastal zone over a short period (Wu et al., 2014), with a serious consequence of water pollution, eutrophication and other damages to the environment (Yang, 2014). Annual discharge of total nitrogen (TN) and total phosphorus (TP) from shrimp mariculture into the Min River Estuary was estimated to 30.45 and $2.40 \mathrm{Mg}$, respectively (Yang et al., 2017a). Consequently, TN and TP concentrations in the receiving waters jumped markedly by $270 \%$ and $234 \%$, respectively (Yang et al., 2017a). This study further estimated that the annual discharge of DOC and DIC from shrimp mariculture into the adjacent coastal waters was 444.1 and $706.2 \mathrm{Mg}$, respectively, for MRE (the total pond area of $26.30 \mathrm{~km}^{2}$, water depth of $1.4 \mathrm{~m}$, and mean DOC and DIC concentrations of 13.5 and $21.5 \mathrm{mg}$ $\mathrm{L}^{-1}$, respectively) and 550.2 and $1264.1 \mathrm{Mg}$, respectively, for JRE (a total pond area of $43.3 \mathrm{~km}^{2}$, water depth of $1.5 \mathrm{~m}$, and mean DOC and DIC concentrations of 8.3 and $18.9 \mathrm{mg} \mathrm{L}^{-1}$, respectively). Considering the total area of China's subtropical estuaries mariculture of $6.6 \times 10^{3} \mathrm{~km}^{2}$ (Yao et al., 2016) and a mean water depth of $1.4 \mathrm{~m}$ and assuming that our data were representative of the mariculture ponds across China, it is estimated that approximately $100 \mathrm{Gg} \mathrm{DOC}^{-1}$ and $190 \mathrm{Gg}$ DIC y$^{-1}$ would be directly discharged from the mariculture ponds into the adjacent coastal zone. The decomposition of organic matter such as DOC was the main driver of the internal $\mathrm{CO}_{2}$ production in aquatic ecosystems (Müller et al., 2015; Weyhenmeyer et al., 2016). The discharge of aquaculture effluents can rapidly alter the supply of organic matter and the quality of nearby waters (Herbeck et al., 2013; Yang et al., 2017c), which subsequently create a favorable environment for $\mathrm{CO}_{2}$ production internally in the coastal ecosystems. Our results pointed to the potential of adjacent 
receiving coastal waters in the effluent discharge area of the ponds being potential "hotspots" of $\mathrm{CO}_{2}$ emissions in winter.

\subsubsection{Management to reduce $\mathrm{CO}_{2}$ emission from aquaculture ponds}

Yang et al. (2018) found variations in $\mathrm{CO}_{2}$ emissions fluxes across the water-air interface from aquaculture ponds among estuaries, with high fluxes in Min River Estuary $\left(17.47 \mathrm{mg} \mathrm{m}^{-2} \mathrm{~h}^{-1}\right)$ and low fluxes in Jiulong River Estuary $\left(15.40 \mathrm{mg} \mathrm{m}^{-2}\right.$ $\left.\mathrm{h}^{-1}\right)$. The variation of $\mathrm{CO}_{2}$ emission fluxes was similar to those of porewater $\mathrm{CO}_{2}$ concentrations (Fig. 4a), overlying water $\mathrm{CO}_{2}$ production rates (Fig. 4b) and sediment $\mathrm{CO}_{2}$ release rates (Fig. 4c). The result indicate that high $\mathrm{CO}_{2}$ emissions were accompanied by high $\mathrm{CO}_{2}$ production and porewater $\mathrm{CO}_{2}$ concentrations. The high variation of $\mathrm{CO}_{2}$ emission and other biogeochemical processes from mariculture ponds is commonly related to multiple environmental factors, but low salinity is necessary to produce high $\mathrm{CO}_{2}$ production and emission fluxes. This implies that increasing salinity level of aquaculture ponds might be an measure to reduce $\mathrm{CO}_{2}$ emission from aquaculture, but the potential impact to other environmental conditions should be monitored and minimized. From 1 January 2015, China has started the new Environmental Protection Law (EPL) and the strict implementation of EPL and related regulations will be the key for the sustainable development of aquaculture in China (Yang, 2014; Yang et al., 2015b).

\subsubsection{Limitation and future research}

Similar as many studies, there are some limitations in the current study. It should be noted that large uncertainties might exist in our estimated contributions of $\mathrm{CO}_{2}$ SP and $\mathrm{CO}_{2}$ WP to the overall $\mathrm{CO}_{2}$ IP rate of aquaculture ponds owing to the limited size of our data sets with only two estuaries. Future research should increase the frequency of in situ sampling, for example the diurnal change (Xing et al., 2004), and include more innovative techniques, to measure $\mathrm{CO}_{2} \mathrm{SP}$ and $\mathrm{CO}_{2}$ WP in aquaculture ponds at multiple spatial scales. Future long-term in situ sampling and monitoring with multiple frequencies in various regions of China should be carried out to obtain a more complete picture of the influence of aquaculture pond effluents on $\mathrm{CO}_{2}$ production and emissions in coastal ecosystems. Furthermore, the aquaculture pond ecosystem is characterized by shallow water depth, high transparency, and high daily feed supply, which together could provide a suitable environment for $\mathrm{CO}_{2}$ production in the water column by photochemical mineralization $\left(\mathrm{CO}_{2} \mathrm{PP}\right)$ and heterotrophic respiration of shrimps $\left(\mathrm{CO}_{2} \mathrm{SR}\right)$. While $\mathrm{CO}_{2}$ PP and $\mathrm{CO}_{2}$ SR are likely important contributors to the internal $\mathrm{CO}_{2}$ production in subtropical aquaculture ponds, the roles of $\mathrm{CO}_{2}$ PP and $\mathrm{CO}_{2}$ SR deserve further investigation. In the current study, $\mathrm{CO}_{2}$ fluxes were analyzed completely based on laboratory incubation experiments, and further in situ experiments will be helpful to unravel the detailed mechanisms of bioturbation on $\mathrm{CO}_{2}$ efflux.

\section{Conclusions}

Carbon dioxide production from sediment and overlying water at aquaculture shrimp ponds in two subtropical estuaries were research in the current study. Significant differences in porewater $\mathrm{CO}_{2}$ concentrations, $\mathrm{CO}_{2}$ wP, and $\mathrm{CO}_{2}$ fluxes across the SWI were observed at the shrimp ponds in subtropical estuaries among 
growth stages, with much higher values in the middle stage. Our results suggested that the seasonal variations in sediment temperature and organic matter supply were the key drivers of the changes in porewater $\mathrm{CO}_{2}$ concentrations and $\mathrm{CO}_{2}$ fluxes, while the temporal variations of $\mathrm{CO}_{2}$ wP were governed by the interactions between organic matter and other abiotic factors (e.g. $\mathrm{pH}$ and salinity). Higher porewater $\mathrm{CO}_{2}$ concentrations and $\mathrm{CO}_{2}$ WP in the MRE than the JRE ponds could be partly attributed to the difference in salinity levels between the two estuaries. Our results further highlighted the importance of considering the variability of $\mathrm{CO}_{2}$ production among different estuaries and aquaculture stages in order to produce reliable extrapolation and estimates of large-scale carbon balances. The mean $\mathrm{CO}_{2}$ fluxes across the SWI in the ponds was approximately 3.9 times larger than the mean $\mathrm{CO}_{2}$ wP rate, suggesting that sediment was an important contributor to the internal $\mathrm{CO}_{2}$ production at the shrimp ponds in subtropical estuaries. Therefore, formulating management strategies in minimizing sediment $\mathrm{CO}_{2}$ release would be crucial for reducing $\mathrm{CO}_{2}$ emissions from aquaculture ponds to the atmosphere in future.

\section{Acknowledgments}

This research was financially supported by the National Science Foundation of China (No. 41801070, 41671088), the Graduate Student Science and Technology Innovation Project of the School of Geographical Science of the Fujian Normal University (GY201601), the Research Grants Council of the Hong Kong Special Administrative Region, China (CUHK458913, 14302014, 14305515), the CUHK Direct Grant (SS15481), Open Research Fund Program of Jiangsu Key Laboratory of Atmospheric Environment Monitoring \& Pollution Control, and Minjiang Scholar Programme. We would like to thank Yi-fei Zhang, and Li-shan Tan of the School of Geographical Sciences, Fujian Normal University for their field assistance.We sincerely thank Prof., David Bastviken for valuable suggestions.

\section{References}

Adams, D.D. 2005. Diffuse flux of greenhouse gases-methane and carbon dioxide-at the sediment-water interface of some lakes and reservoirs of the world. In: Tremblay A, Varfalvy L, Roehm C, Garneau M [eds.] Greenhouse gas emissions-fluxes and processes. Springer, Berlin, p 129-153.

Algesten, G., Sobek, S., Bergström, A.K., Jonsson, A., Tranvik, L.J., Jansson, M., 2005. Contribution of sediment respiration to summer $\mathrm{CO}_{2}$ emission from low productive boreal and subarctic lakes. Microb. Ecol. 50, 529-535. doi: 10.1007/s00248-005-5007-x

Almeida, R.M., Nóbrega, G.N., Junger, P.C., Figueiredo, A.V., Andrade, A.S., de Moura, C.G.B., Tonetta, D., Oliveira Jr., E.S., Araújo, F., Rust, F., Piñeiro-Guerra, J.M., Mendonça Jr., J.R., Medeiros, L.R., Pinheiro, L., Miranda, M., Costa, M.R.A., Melo, M.L., Nobre, R.L.G., Benevides, T., Roland, F., de Klein, J., Barros, N.O., Mendonça, R., Becker, V., Huszar, V.L.M., Kosten, S., 2016. High primary production contrasts with intense carbon emission in a eutrophic tropical reservoir. Front. Microbiol. 7, 717. doi: 10.3389/fmicb.2016.00717

Boyd, C.E., Wood, C.W., Chaney, P.L., Queiroz, J.F., 2010. Role of aquaculture pond sediments in sequestration of annual global carbon emissions. Env. Poll. 158, 2537-2540. doi: 10.1016/j.envpol.2010.04.025

Brothers, S.M., Prairie, Y.T., Del Giorgio, P.A., 2012. Benthic and pelagic sources of carbon dioxide in boreal lakes and a young reservoir (Eastmain-1) in eastern Canada. Glob. Biogeochem. Cycles. 26, GB1002. doi: 10.1029/2011GB004074 
Burford, M.A., Thompson, P.J., McIntosh, R.P., Bauman, R.H., Pearson, D.C., 2003. Nutrient and microbial dynamics in high-intensity, zero-exchange shrimp ponds in Belize. Aquaculture 219, 393-411. doi: 10.1016/S0044-8486(02)00575-6

Casper, P., Furtado, A., Adams, D.D., 2003. Biogeochemistry and diffuse fluxes of greenhouse gases (methane and carbon dioxide) and dinitrogen from the sediments in oligotrophic Lake Stechlin. In: Koschel, R., Adams, D.D., (Eds) Lake Stechlin: an approach to understand an oligotrophic lowland lake. Arch. Hydrobiol. Spec. Iss. Adv. Limnol. 58, 53-71.

Chen, Y., Dong, S.L., Wang, F., Gao, Q.F., Tian, X.L., 2016. Carbon dioxide and methane fluxes from feeding and no-feeding mariculture ponds. Env. Poll. 212, 489-497. doi: 10.1016/j.envpol.2016.02.039

Chen, Y., Dong, S.L., Wang, Z.N., Wang, F., Gao, Q.F., Tian, X.L., Xiong, Y.H., 2015. Variations in $\mathrm{CO}_{2}$ fluxes from grass carp Ctenopharyngodon idella aquaculture polyculture ponds. Aquacult. Environ. Interact. 8, 31-40. doi: 10.3354/aei00149

Crawford, J.T.,Striegl, R.G., Wickland, K.P., Dornblaser, M.M., Stanley, E.H., 2013. Emissions of carbon dioxide and methane from a headwater stream network of interior Alaska. J. Geophys. Res. Biogeosci. 118, 482-494. doi: 10.1002/jgrg.20034

De Vittor, C., Faganeli, J., Emili, A., Covelli, S., Predonzani, S., Acquavita, A., 2012. Benthic fluxes of oxygen, carbon and nutrients in the Marano and Grado Lagoon (northern Adriatic Sea, Italy). Estuar. Coast. Shelf S. 113, 57-70. doi: 10.1016/j.ecss.2012.03.031

Ding, W.X., Zhang, Y.H., Cai, Z.C., 2010. Impact of permanent inundation on methane emissions from a Spartina alterniflora coastal salt marsh. Atmos. Environ. 44, 3894-3900. doi: 10.1016/j.atmosenv.2010.07.025

Dutta, M.K., Mukherjee, R., Jana, T.K., Mukhopadhyay, S.K., 2015. Biogeochemical dynamics of exogenous methane in an estuary associated to a mangrove biosphere; The Sundarbans, NE coast of India. Mar. Chem. 170, 1-10. doi: 10.1016/j.marchem.2014.12.006

FAO, 2014. The State of World Fisheries and Aquaculture. Food and Agricultural Organization of the United Nations, Rome, Italy.

Golovatskaya, E.A., Dyukarev, E.A., 2009. Carbon budget of oligotrophic mire sites in the Southern Taiga of Western Siberia. Plant. Soil. 315, 19-34. doi: 10.1007/s11104-008-9842-7

Gruca-Rokosz, R., Tomaszek, J.A., 2015. Methane and carbon dioxide in the sediment of a eutrophic reservoir: production pathways and diffusion fluxes at the sediment-water interface. Water. Air. Soil. Poll. 226, 16. doi: 10.1007/s11270-014-2268-3

Gruca-Rokosz, R., Tomaszek, J.A., Koszelnik, P., Czerwieniec, E., 2011. Methane and carbon dioxide fluxes at the sediment-water interface in reservoirs. Polish J. Environ. Stud. 20(1), 81-86.

Gu, Y.G., Ouyang, J., Ning, J.J., Wang, Z.H., 2017a. Distribution and sources of organic carbon, nitrogen and their isotopes in surface sediments from the largest mariculture zone of the eastern Guangdong coast, South China. Mar. Pollut. Bull. 120, 286-291. doi: 10.1016/j.marpolbul.2017.05.013

Gu, Y.G., Ouyang, J., An, H., Jiang, S.J., Tang. H.Q., 2017b. Risk assessment and seasonal variation of heavy metals in settling particulate matter (SPM) from a typical southern Chinese mariculture base. Mar. Pollut. Bull. 123, 404-409. doi: 10.1016/j.marpolbul.2017.08.044

Guerrero-Galván, S.R., Páez-Osuna, F., Ruiz-Fernández, A.C., Espinoza-Angulo, R., 1999. Seasonal variation in the water quality and chlorophyll $a$ of semi-intensive shrimp ponds in a subtropical environment. Hydrobiologia. 391, 33-45. doi: 10.1023/A:100359062

Hansen, K., Kristensen, E., 1997. Impact of macrofaunal recolonization on benthic metabolism and nutrient fluxes in a shallow marine sediment previously overgrown with macroalgal mats. Estuar. Coast.Shelf S. 45(5), 613-628. doi: 10.1006/ecss.1996.0229

Herbeck, L.S., Unger, D., Wu, Y., Jennerjahn, T.C., 2013. Effluent, nutrient and organic matter export from shrimp and fish ponds causing eutrophication in coastal and back-reef waters of NE Hainan, tropical China. Cont. Shelf Res. 57, 92-104. doi: 10.1016/j.csr.2012.05.006 
Holgerson, M.A., Raymond, P.A., 2016. Large contribution to inland water $\mathrm{CO}_{2}$ and $\mathrm{CH}_{4}$ emissions from very small ponds. Nat. Geosci. 9, 222-226. doi: 10.1038/NGEO2654

Hu, M.J., Ren, H.C., Ren, P., Li, J.B., Wilson, B.J., Tong, C., 2017. Response of gaseous carbon emissions to low-level salinity increase in tidal marsh ecosystem of the Min River estuary, southeastern China. J. Environ. Sci. 52, 210-222. doi: 10.1016/j.jes.2016.05.009

Jeffrey, S.W., Humphrey, G.F., 1975. New spectrophotometric equations for determining chlorophylls $a, b, c_{1}$ and $c_{2}$ in higher plants, algae and natural phytoplankton. Biochemie und Physiologic der Pflanzen. 167, 191-194. doi: 10.1016/0022-2860(75)85046-0

Johnson, K.M., Hughes, J.E., Donaghay, P.L., Sieburth, J.M., 1990. Bottle-calibration static headspace method for the determination of methane dissolved in seawater. Anal. Chem. 62, 2408-2412. doi: 10.1021/ac00220a030

Kikuchi, E., 1986. Contribution of the polychaete, Neanthes japonica (Izuka), to the oxygen uptake and carbon dioxide production of an intertidal mud-flat of the Nanakita River estuary, Japan. J. Exp. Mar. Biol. Ecol. 97, 81-93. doi: 10.1016/0022-0981(86)90069-9

Kristensen, E., Bouillon, S., Dittmar, T., Marchand C., 2008. Organic carbon dynamics in mangrove ecosystems: a review. Aquat. Bot. 2, 201-219. doi: 10.1016/j.aquabot.2007.12.005

Lafleur, P.M., Moore, T.R., Roulet, N.T., Frolking, S., 2005. Ecosystem respiration in a cool temperate bog depends on peat temperature but not water table. Ecosystems 8, 619-629. doi: 10.1007/s10021-003-0131-2

Liikanen, A.N.U., Murtoniemi, T., Tanskanen, H., Väisänen, T., Martikainen, P.J., 2002. Effects of temperature and oxygen availability on greenhouse gas and nutrient dynamics in sediment of a eutrophic mid-boreal lake. Biogeochemistry. 59(3), 269-286. doi: 10.1023/A:101601552

Molnar, N., Welsh, D.T., Marchand, C., Deborde, J., Meziane, T., 2013. Impacts of shrimp farm effluent on water quality, benthic metabolism and $\mathrm{N}$-dynamics in a mangrove forest (New Caledonia). Estuar. Coast. Shelf S. 117, 12-21. doi: 10.1016/j.ecss.2012.07.012

Mosier, A.R., 1998. Soil processes and global change. Biol. Fertil. Soils. 27(3), 221-229. doi: $10.1007 / \mathrm{s} 003740050$

Morse, J.W., Rowe, G.T., 1999. Benthic biogeochemistry beneath the Mississippi River plume. Estuaries. 22(2), 206-214. doi: 10.2307/1352977

Mu, D., Yuan, D.K., Feng, H., Xing, F.W., Teo, F.Y., Li, S.Z., 2017. Nutrient fluxes across sediment-water interface in Bohai Bay Coastal Zone, China. Mar. Pollut. Bull. 114(2), 705-714. doi: 10.1016/j.marpolbul.2016.10.056

Müller, D., Warneke, T., Rixen, T., Müller, M., Mujahid, A., Bange, H.W., Notholt, J., 2016. Fate of terrestrial organic carbon and associated $\mathrm{CO}_{2}$ and $\mathrm{CO}$ emissions from two Southeast Asian estuaries. Biogeosciences. 13, 691-705. doi:10.5194/bg-13-691-2016

Myhre, G., Shindell, D., Bréon, F.-M., Collins, W., Fuglestvedt, J., Huang, J., Koch, D., Lamarque, J.-F., Lee, D., Mendoza, B., Nakajima, T., Robock, A., Stephens, G., Takemura, T., Zhang, H., 2013. Anthropogenic and Natural Radiative Forcing, in: Stocker, T., Qin, D., Plattner, G.-K., Tignor, M., Allen, S., Boschung, J., Nauels, A., Xia, Y., Bex, V., Midgley, [Eds.]. Climate Change 2013: The Physical Science Basis. Contribution of Working Group I to the Fifth Assessment Report of the Intergovernmental Panel on Climate Change. Cambridge University Press, Cambridge, United Kingdom and New York, NY, USA.

Neal, C., House, W.A., Jarvie, H.P., Eatherall, A., 1998. The significance of dissolved carbon dioxide in major lowland rivers entering the North Sea. Sci. Total. Environ. 210-211, 187-203. doi: 10.1016/S0048-9697(98)00012-6

Ogrinc, N., Lojen, S., Faganeli, J., 2002. A mass balance of carbon stable isotopes in an organic-rich methane-producing lacustrine sediment (Lake Bled, Slovenia). Global. Planet. Change, 33, 57-72. doi: 10.1016/S0921-8181(02)00061-9

Raymond, P.A., Hartmann, J., Lauerwald, R., Sobek, S., McDonald, C., Hoover, M., Butman, D., Striegl, R., Mayorga, E., Humborg, C., Kortelainen, P., Durr, H., Meybeck, M., Ciais, P., Guth, P., 2013. Global carbon dioxide emissions from inland waters. Nature 503, 355-359. doi: 10.1038/nature 12760 
Schrier-Uijl, A.P., Veraart, A.J., Leffelaar, P.A., Berendse, F., Veenendaal, E.M., 2011. Release of $\mathrm{CO}_{2}$ and $\mathrm{CH}_{4}$ from lakes and drainage ditches in temperate wetlands. Biogeochemistry 102, 265-279. doi: 10.1007/s10533-010-9440-7

Sidik, F., Lovelock, C.E., 2013. $\mathrm{CO}_{2}$ efflux from shrimp ponds in Indonesia. PLOS ONE. 8(6), e66329. doi:10.1371/journal.pone.0066329

Silva, K.R., Wasielesky, Jr.W., Abreu, P.C., 2013. Nitrogen and phosphorus dynamics in the biofloc production of the Pacific white shrimp, Litopenaeus vannamei. J. Word Aquacult. Soc. 44(1), 30-41. doi: 10.1111/jwas.12009

Sun, Z.G., Wang, L.L., Tian, H.Q., Jiang, H.H., Mou, X.J., Sun, W.L., 2013. Fluxes of nitrous oxide and methane in different coastal Suaeda salsa marshes of the Yellow River estuary, China. Chemosphere. 90(2), 856-865. doi: 10.1016/j.chemosphere.2012.10.004

Tan, Y.J., 2014. The greenhouse gases emission and production mechanism from river sediment in Shanghai. Thesis, East China Normal University, Shanghai. (in Chinese)

Tangen, B.A., Finocchiaro, R.G., Gleason, R.A., Dahl, C.F., 2016. Greenhouse gas fluxes of a shallow lake in south-central North Dakota, USA. Wetlands 36, 779-787. doi: 10.1007/s 13157-016-0782-3

Tonetta, D., Staehr, P.A., Petrucio, M.M., 2017. Changes in $\mathrm{CO}_{2}$ dynamics related to rainfall and water level variations in a subtropical lake. Hydrobiologia. 794(1), 109-123. doi: $10.1007 / \mathrm{s} 1075$

Tong, C., Morris, J.T., Huang, J.F., Xu, H., Wan, S.A., 2018. Changes in pore-water chemistry and methane emission following the invasion of Spartina alterniflora into an oliogohaline marsh. Limnol. Oceanogr. 63, 384-396. doi: 10.1002/1no.10637

Tong, C., Wang, W.Q., Zeng, C.S., Marrs, R., 2010. Methane emissions from a tidal marsh in the Min River estuary, southeast China. J. Environ. Sci. Heal. A. 45, 506-516. doi: 10.1080/10934520903542261

Tong, C., Wang, W.Q., Huang, J.F., Gauci, V., Zhang, L.H., Zeng, C.S., 2012. Invasive alien plants increase $\mathrm{CH}_{4}$ emissions from a subtropical tidal estuarine wetland. Biogeochemistry. 111, 677-693. doi: 10.1007/s10533-012-9712-5

Urban, N.R., Dinkel, C., Wehrli, B., 1997. Solute transfer across the sediment surface of a eutrophic lake: I. Pore water profiles from dialysis samplers. Aquatic. Sci. 59(1), 1-25. doi: 10.1007/BF02522546

Vachon, D., Lapierre, J.F., Del Giorgio, P.A., 2016. Seasonality of photochemical dissolved organic carbon mineralization and its relative contribution to pelagic $\mathrm{CO}_{2}$ production in northern lakes. J. Geophys. Res. Biogeosci. 121, 864-878. doi: 10.1002/2015JG003244

Vreča, P., 2003. Carbon cycling at the sediment-water interface in a eutrophic mountain lake (Jezero na Planini pri Jezeru, Slovenia). Org. Geochem. 34(5), 671-680. doi: 10.1016/S0146-6380(03)00022-6

Wallin, M., Buffam, I., Oquist, M., Laudon, H., Bishop., K., 2010. Temporal and spatial variability of dissolved inorganic carbon in a boreal stream network: Concentrations and downstream fluxes. J. Geophys. Res-Biogeo. 115, G02014. doi: 10.1029/2009jg001100

Wanninkhof, R., 1992. Relationship between wind speed and gas exchange over the ocean. J. Geophys. Rese-Oceans. 97(C5), 7373-7382. doi: 10.3878/j.issn.1006-9895.2012.11182

Weyhenmeyer, G.A., Kosten, S., Wallin, M.B., Tranvik, L.J., Jeppesen, E., Roland, F., 2015. Significant fraction of $\mathrm{CO}_{2}$ emissions from boreal lakes derived from hydrologic inorganic carbon inputs. Nat. Geosci. 8(12), 933-936. doi: 10.1038/ngeo2582

Wiesenburg, D.A., Guinasso Jr., N.L., 1979. Equilibrium solubilities of methane, carbon dioxide, and hydrogen in water and sea water. J. Chem. Eng. Data. 24, 356-360. doi: $10.1021 /$ je60083a006

Wollast, R., 1993. Interactions of carbon and nitrogen cycles in the coastal zone. In: Wollast, R., F. T. Mackenzie, and L. Chou [Eds.], Interactions of C, N, P and S Biogeochemical Cycles and Global Change, NATO ASI Series, Series 1: Global Environmental Change 4. Springer-Verlag, Berlin and Heidelberg, pp. 195-210.

World Meteorological Organization, 2018. WMO Greenhouse Gas Bulletin No. 14. https://library.wmo.int/doc_num.php?explnum_id=5455. 
Wu, H., Peng, R., Yang, Y., He, L., Wang, W.Q., Zheng, T.L., Lin, G.H., 2014. Mariculture pond influence on mangrove areas in south China: Significantly larger nitrogen and phosphorus loadings from sediment wash-out than from tidal water exchange. Aquaculture. 426, 204-212. doi: 10.1016/j.aquaculture.2014.02.009

Xiang, J., Liu, D.Y., Ding, W.X., Yuan, J.J., Lin, Y.X., 2015. Invasion chronosequence of Spartina alterniflora on methane emission and organic carbon sequestration in a coastal salt marsh. Atmos. Environ. 112, 72-80. doi: 10.1016/j.atmosenv.2015.04.035

Xing, Y.P., Xie, P., Yang, H., Ni, L.Y., Wang, Y.S., Tang, W.H., 2004. Diel variation of methane fluxes in summer in a eutrophic subtropical lake in china. Journal of Freshwater Ecology $19,639-644$.

Xing, Y., Xie, P., Yang, H., Ni, L., Wang, Y., Rong, K., 2005. Methane and carbon dioxide fluxes from a shallow hypereutrophic subtropical lake in china. Atmospheric Environment 39, 5532-5540.

Xing, Y.P., Xie, P., Yang, H., Wu, A.P., Ni, L.Y., 2006. The change of gaseous carbon fluxes following the switch of dominant producers from macrophytes to algae in a shallow subtropical lake of china. Atmospheric Environment 40, 8034-8043.

Xiong, Y.H., Wang, F., Guo, X.T., Liu, F., Dong, S.L., 2017. Carbon dioxide and methane fluxes across the sediment-water interface in different grass carp Ctenopharyngodon idella polyculture models. Aquacult. Environ. Interact. 9, 45-56. doi: 10.3354/aei00214.

Yang, H., 2014. China must continue the momentum of green law. Nature 509, 535-353.

Yang, H., Andersen, T., Dörsch, P., Tominaga, K., Thrane, J.-E., Hessen, D.O., 2015a. Greenhouse gas metabolism in Nordic boreal lakes. Biogeochemistry 126, 211-225.

Yang H., Flower R.J. 2012. Potentially massive greenhouse-gas sources in proposed tropical dams. Frontiers in Ecology and the Environment 10, 234-235.

Yang, H., Xie, P., Ni, L., Flower, R.J., 2011. Underestimation of $\mathrm{CH}_{4}$ emission from freshwater lakes in china. Environmental Science Technology 45, 4203-4204.

Yang, H., Xing, Y., Xie, P., Ni, L., Rong, K. 2008. Carbon source/sink function of a subtropical, eutrophic lake determined from an overall mass balance and a gas exchange and carbon burial balance. Environmental Pollution 151, 559-568.

Yang, P., He, Q.H., Huang, J.F., Tong, C., 2015b. Fluxes of greenhouse gases at two different aquaculture ponds in the coastal zone of southeastern China. Atmos. Environ. 115, 269-277. doi: 10.1016/j.atmosenv.2015.05.067

Yang, P., Lai, D.Y.F., Jin, B.S., Bastviken, D., Tan, L.S., Tong, C., 2017a. Dynamics of dissolved nutrients in the aquaculture shrimp ponds of the Min River estuary, China: Concentrations, fluxes and environmental loads. Sci. Total Environ. 603-604, 256-267. doi: 10.1016/j.scitotenv.2017.06.074

Yang, P., Bastviken, D., Jin, B.S., Mou, X.J., Tong, C., 2017b. Effects of coastal marsh conversion to shrimp aquaculture ponds on $\mathrm{CH}_{4}$ and $\mathrm{N}_{2} \mathrm{O}$ emissions. Estuar. Coast. Shelf S. 199, 125-131. doi: 10.1016/j.ecss.2017.09.023

Yang, P., Lai, D.Y.F., Huang, J.F., Tong, C., 2017c. Effect of drainage on $\mathrm{CO}_{2}, \mathrm{CH}_{4}$, and $\mathrm{N}_{2} \mathrm{O}$ fluxes from aquaculture ponds during winter in a subtropical estuary of China. J. Environ. Sci. 65, 72-82. doi: 10.1016/j.jes.2017.03.024

Yang, P., Jin, B.S., Tan, L.S., Tong, C., 2018a. Spatial-temporal variations of water column dissolved carbon concentrations and dissolved carbon flux at the sediment-water interface in the shrimp ponds from two subtropical estuaries. Acta Ecol. Sinica. 38(6). doi: 10.5846/stxb201702210284. (in Chinese).

Yang, P., Zhang, Y.F., Lai, D.Y.F., Tan, L.S., Jin, B.S., Tong, C., 2018b. Fluxes of carbon dioxide and methane across the water-atmosphere interface of aquaculture shrimp ponds in two subtropical estuaries: The effect of temperature, substrate, salinity and nitrate, Sci. Total Environ., 635, 1025-1035. 
Yao, Y.C., Ren, C.Y., Wang, Z.M., Wang, C., Deng, P.Y., 2016. Monitoring of salt ponds and aquaculture ponds in the coastal zone of China in 1985 and 2010. Wet. Sci. 14(6), 874-882 (in Chinese).

Zhang, G.L., Zhang, J., Liu, S.M., Ren, J.L., Zhao, Y.C., 2010a. Nitrous oxide in the Changjiang (Yangtze River) Estuary and its adjacent marine area: riverine input, sediment release and atmospheric fluxes. Biogeosciences. 7, 3505-3516. doi: 10.5194/bg-7-3505-2010

Zhang, L., Wang, L., Yin, K.D., Lü, Y., Zhang, D.R., Yang, Y.Q., Huang, X.P., 2013. Pore water nutrient characteristics and the fluxes across the sediment in the Pearl River estuary and adjacent waters, China. Estuar. Coast. Shelf S. 133, 182-192. doi: 10.1016/j.ecss.2013.08.028

Zhang, Y.H., Ding, W.X., Cai, Z.C., Valerie, P., Han, F.X., 2010b. Response of methane emission to invasion of Spartina alterniflora and exogenous N deposition in the coastal salt marsh. Atmos. Environ. 44, 4588-4594. doi: 10.1016/j.atmosenv.2010.08.012

Zheng, Z.M., Dong, S.L., Tian, X.L., Wang, F., Gao, Q.F., Bai, P.F., 2009. Sediment water fluxes of nutrients and dissolved organic carbon in extensive sea cucumber culture ponds. Clean-Soil Air Water. 37, 218-224. doi: 10.1002/clen.200800193

Zhong, D.S., Wang, F., Dong, S.L., Li, L., 2015. Impact of Litopenaeus vannamei bioturbation on nitrogen dynamics and benthic fluxes at the sediment-water interface in pond aquaculture. Aquacult. Int. 23(4), 967-980. doi: 10.1007/s1049 


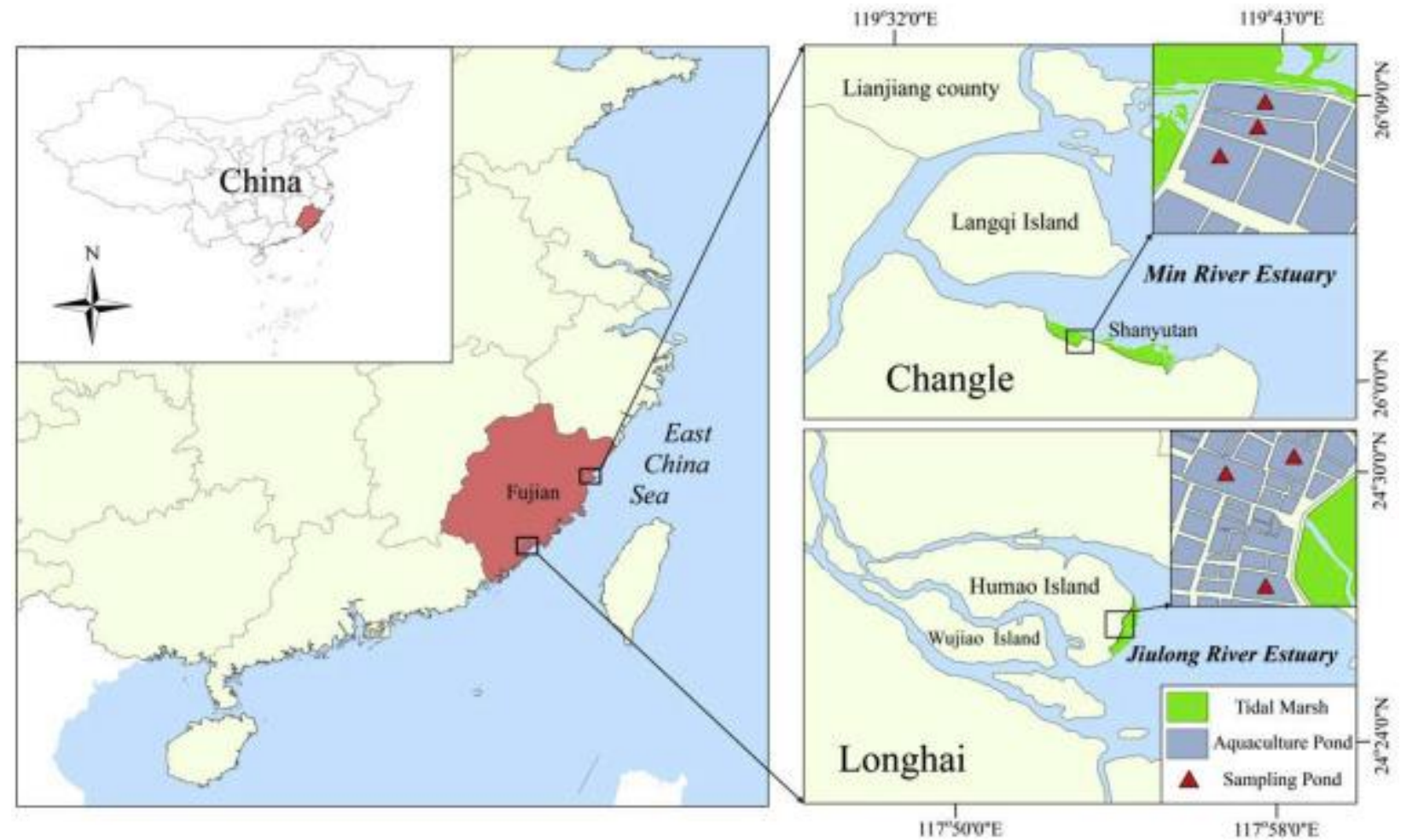

Fig. 1. Location of the study area and sampling sites in the Min River Estuary and Jiulong River Estuary, Fujian, Southeast China (Yang et al., 2018b). 

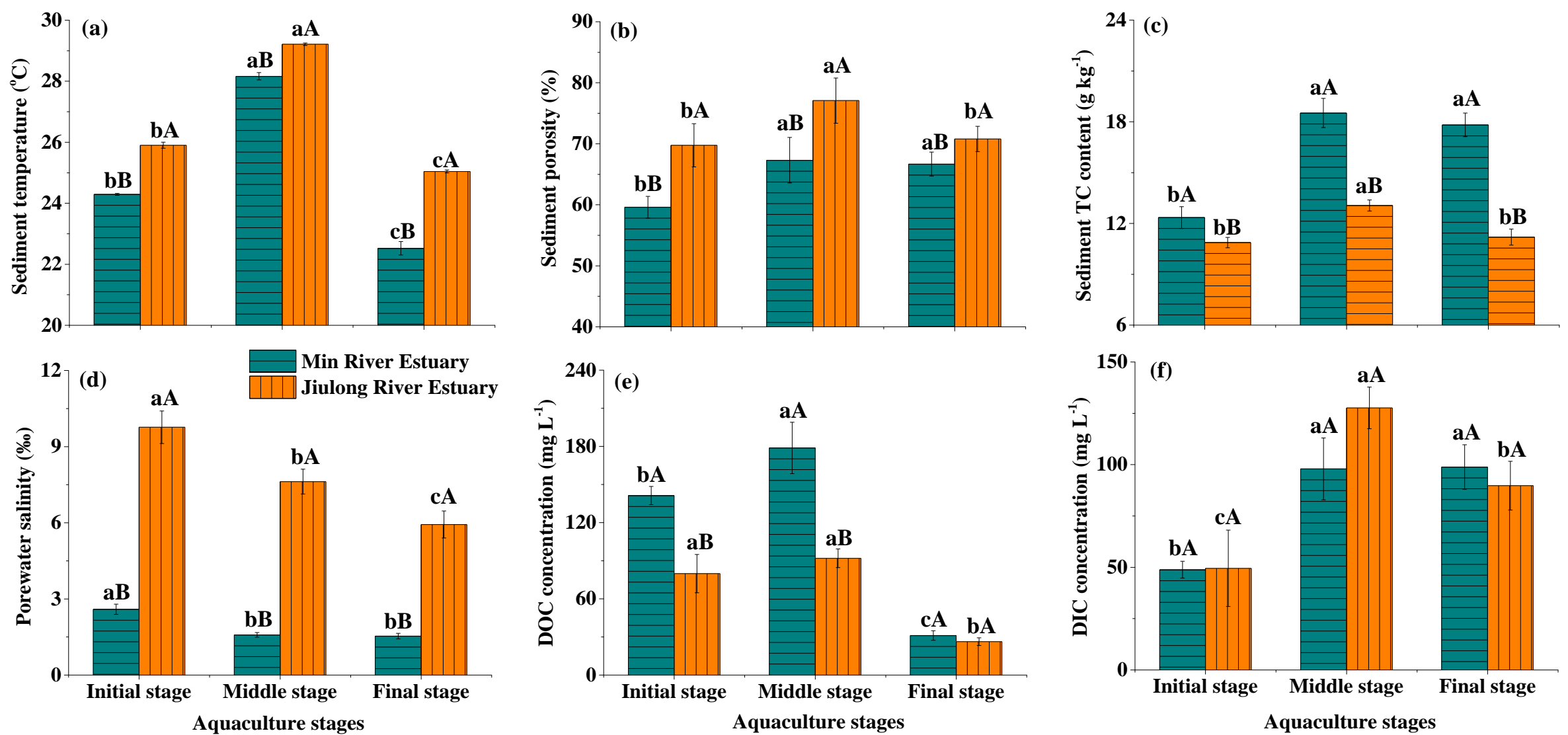

Fig. 2. Variations in (a) temperature, (b) porosity, and (c) total carbon (TC) in surface (0-15 cm) sediments, and (d) salinity, (e) dissolved organic carbon (DOC), and (f) dissolved inorganic carbon (DIC) concentrations in the sediment porewater of shrimp ponds at the Min River Estuary (MRE) and Jiulong River Estuary (JRE).

Bars represent means $\pm 1 \mathrm{SE}(n=9)$. Different lowercase and uppercase letters on the bars indicate significant differences among different growth stages and

estuaries, respectively $(p<0.05)$. 

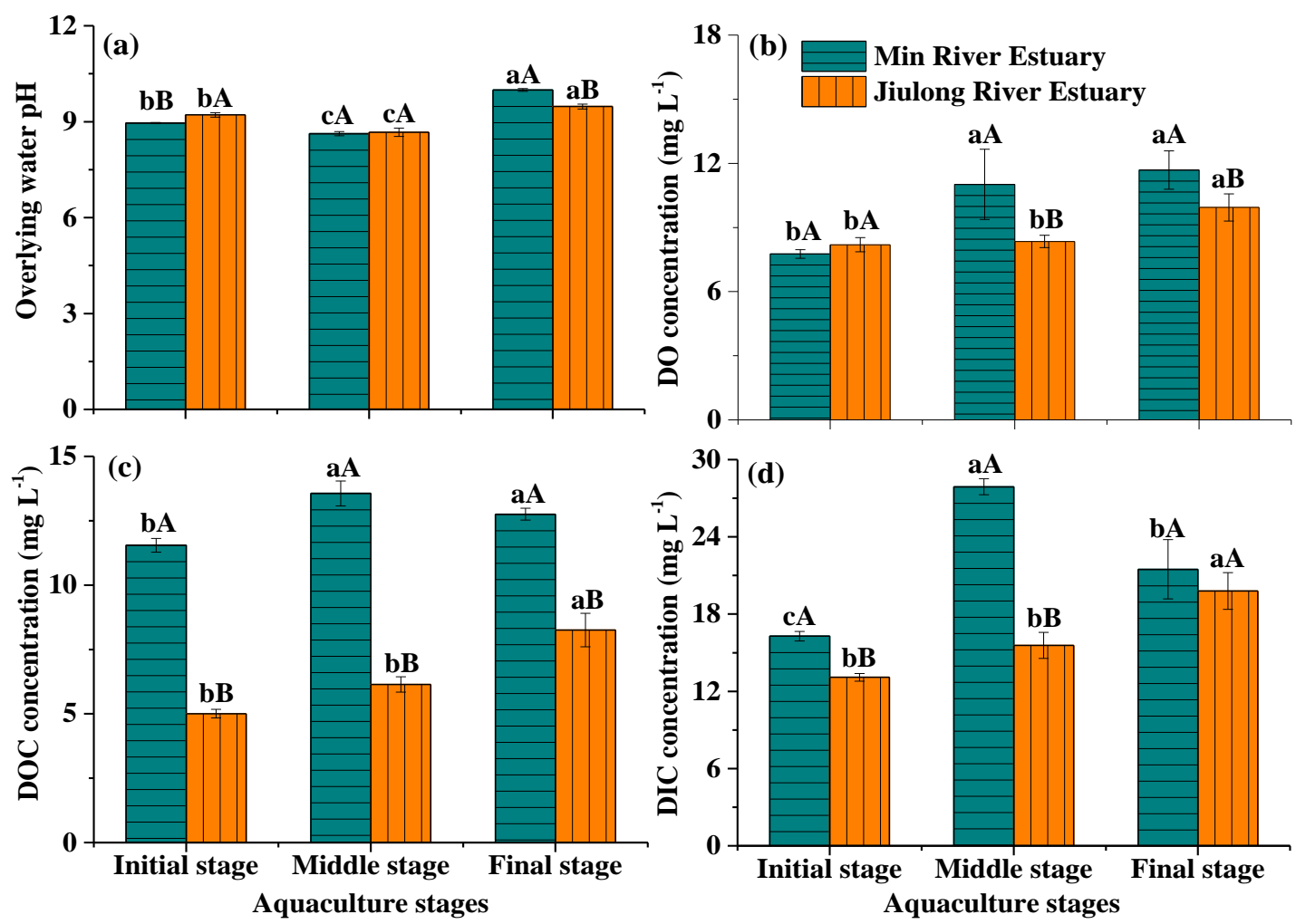

Fig. 3. Variations in (a) pH, (b) dissolved oxygen (DO), (c) dissolved organic carbon (DOC) and (d) dissolved inorganic carbon (DIC) in the overlying water of shrimp ponds at the Min River Estuary and Jiulong River Estuary. Bars represent means \pm 1 SE $(n=9)$. Different lowercase and uppercase letters on the bars indicate significant differences among different growth stages and estuaries, respectively $(p<0.05)$. 

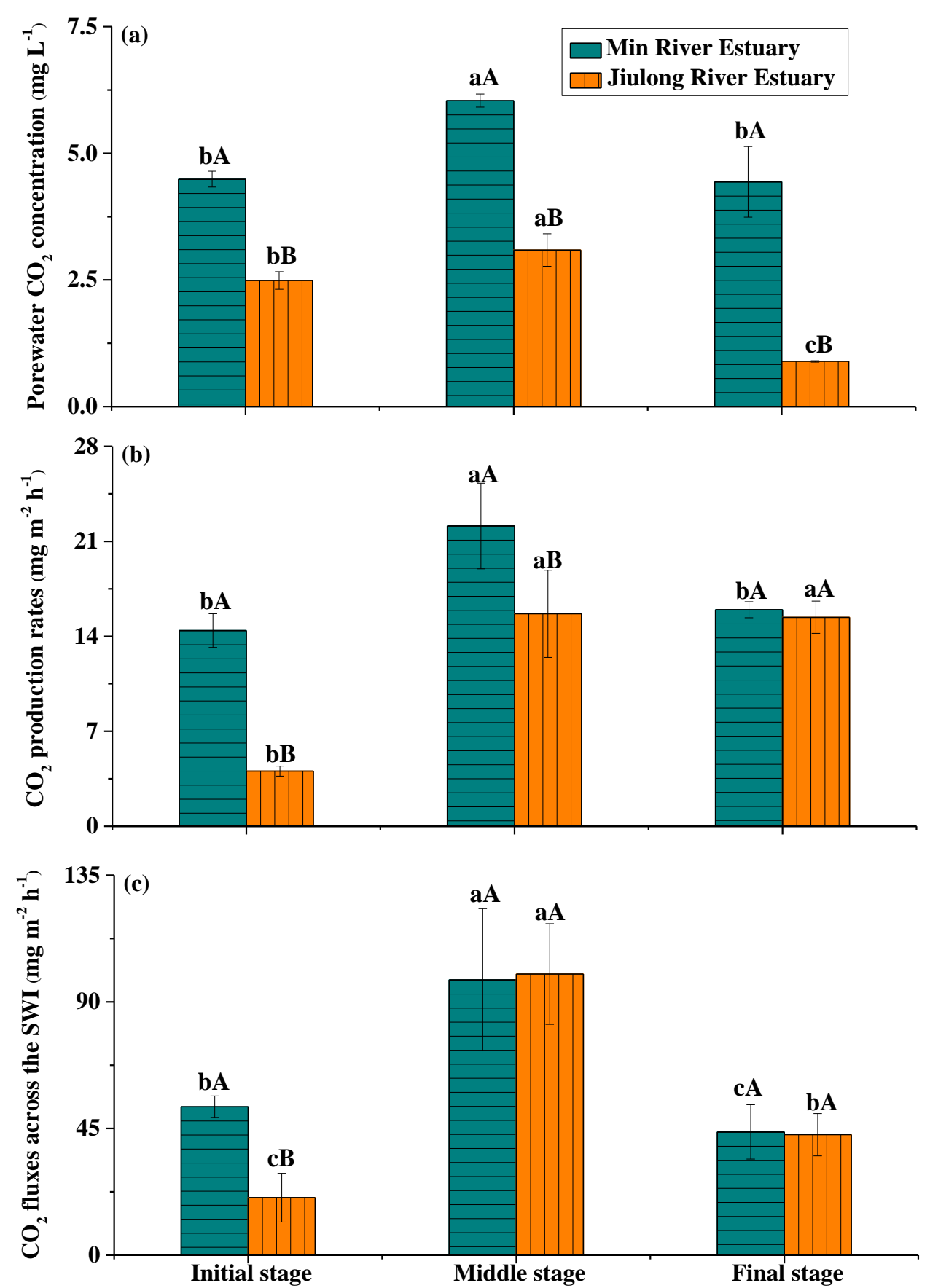

880 Fig. 4. Variations in (a) sediment porewater $\mathrm{CO}_{2}$ concentration, (b) overlying water $\mathrm{CO}_{2}$ 881 production rate $\left(\mathrm{CO}_{2}\right.$ WP $)$, and (c) $\mathrm{CO}_{2}$ fluxes across the sediment-water interface (SWI) of shrimp 882 ponds at the Min River Estuary and Jiulong River Estuary. Bars represent means \pm 1 SE $(n=9)$. 883 Different lowercase and uppercase letters on the bars indicate significant differences among 884 different growth stages and estuaries, respectively $(p<0.05)$. 

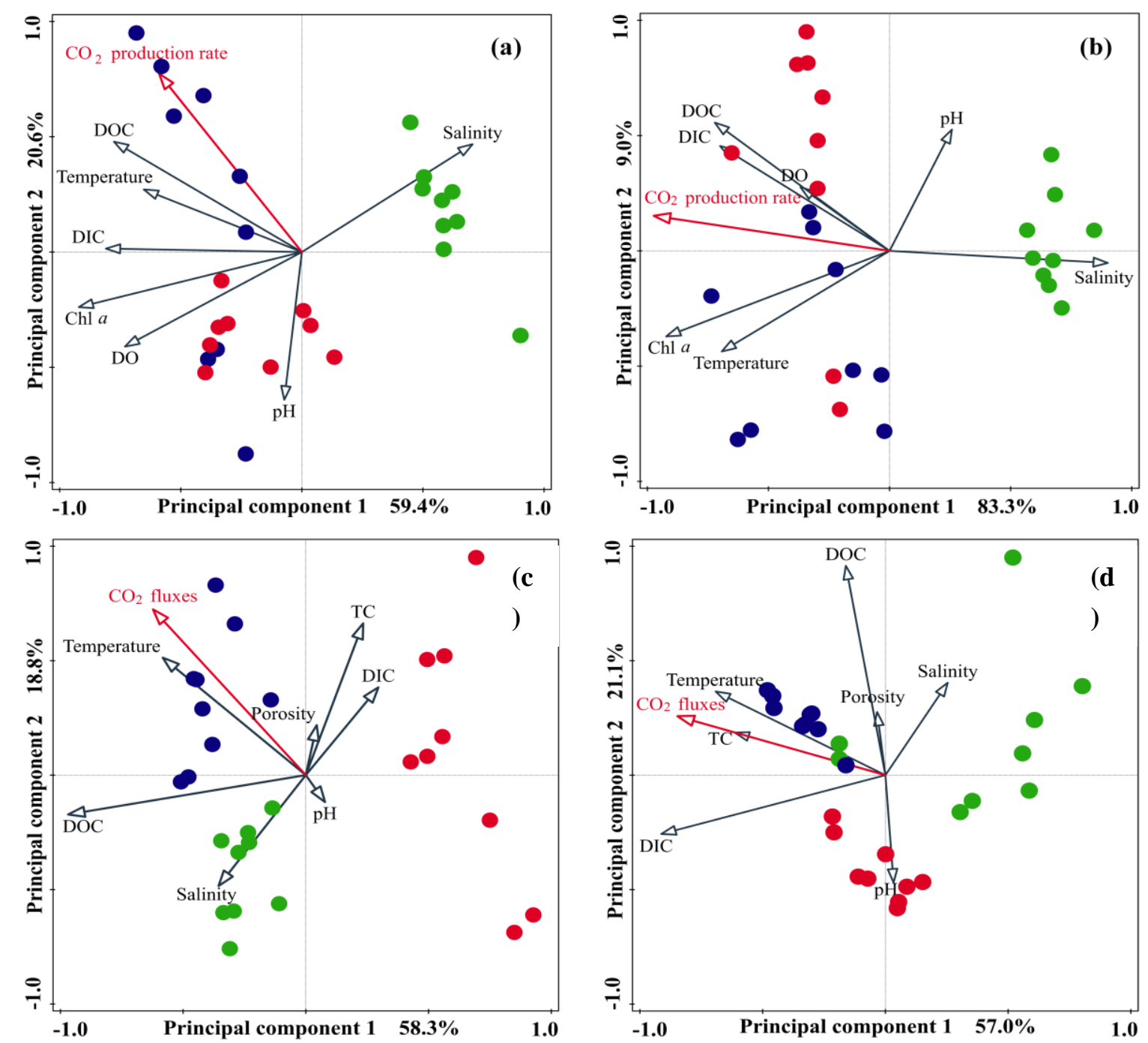

- Initial stage $\bullet$ Middle stage $\bullet$ Final stage

886 Fig. 5. The principal component analysis biplots of the $\mathrm{CO}_{2}$ production rates in the overlying water, $\mathrm{CO}_{2}$ fluxes across the SWI and various environmental factors of (a, c) Min River Estuary and (b, d) Jiulong River Estuary ponds, showing the loadings of environmental factors (arrows) and the scores of observations in different aquaculture stages (points). 

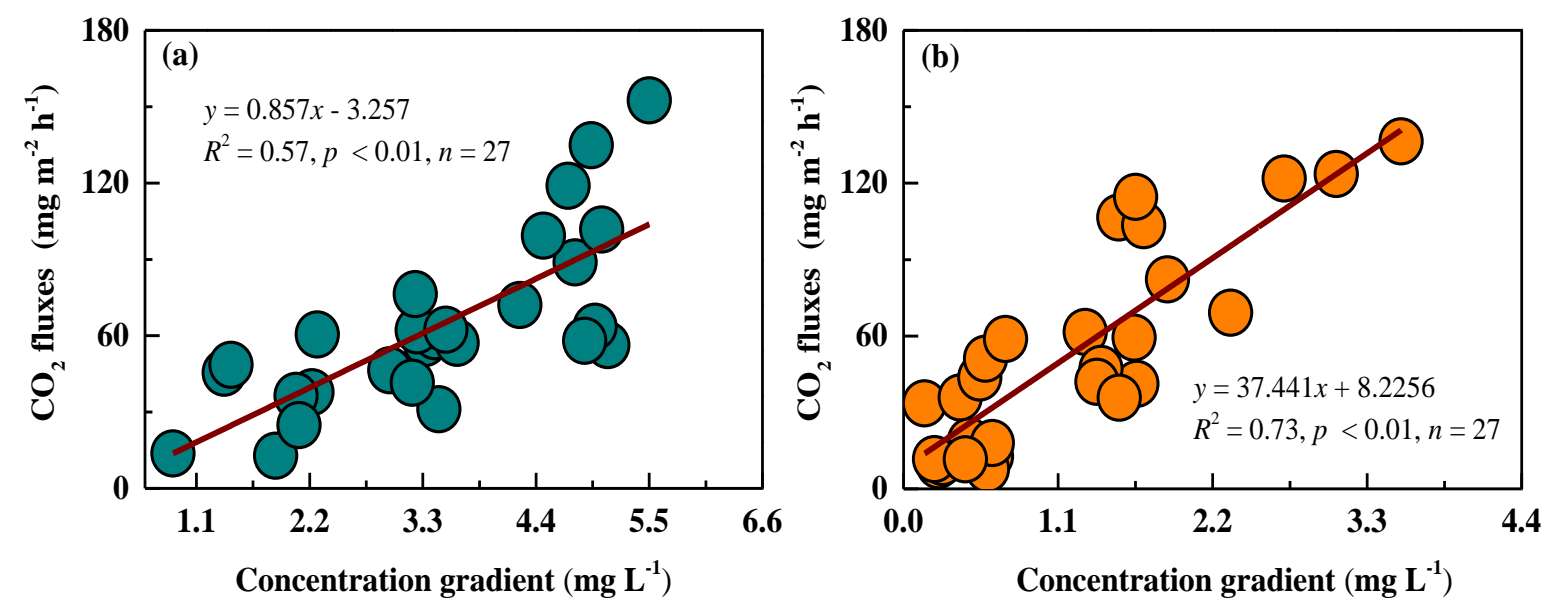

890

Fig. 6. Relationships between $\mathrm{CO}_{2}$ fluxes and $\mathrm{CO}_{2}$ concentration gradients across the SWI of 892 shrimp ponds at the (a) Min River Estuary and (b) Jiulong River Estuary. The solid lines represent 893 the best-fit linear regression $(p<0.01)$.

894 
Table 1

896 Results of two-way ANOVA of the effects of estuaries and aquaculture stages on sediment porewater $\mathrm{CO}_{2}$ concentrations, $\mathrm{CO}_{2}$ production rates, and $\mathrm{CO}_{2}$ fluxes across the SWI of shrimp

898 ponds at the Min River Estuary and Jiulong River Estuary.

\begin{tabular}{lllll}
\hline & $d f$ & Porewater $\mathrm{CO}_{2}$ & $\mathrm{CO}_{2}$ production & $\mathrm{CO}_{2}$ fluxes \\
\hline Estuaries & 1 & $67.240^{* *}$ & $18.674^{* *}$ & 1.980 \\
Aquaculture stages & 2 & $10.162^{*}$ & $17.889^{* *}$ & $33.557 * *$ \\
Aquaculture stages $\times$ Estuaries & 2 & 1.700 & $4.513^{*}$ & 3.094 \\
\hline
\end{tabular}

899

$* * p<0.001, * p<0.01$. 
Table 2

901 Pearson correlation coefficients for porewater $\mathrm{CO}_{2}$ concentrations and various physico-chemical

902 parameters of porewater and sediments in the shrimp ponds of the Min River Estuary (MRE) and

903 Jiulong River Estuary (JRE).

\begin{tabular}{llllllll}
\hline \multirow{2}{*}{ Estuary } & Porewater & \multicolumn{7}{c}{ Sediment } \\
\cline { 2 - 7 } & DOC & DIC & Salinity & Temperature & Porosity & TC & pH value \\
\hline MRE & $0.451^{*}$ & NS & NS & $0.398^{*}$ & NS & NS & $-0.392^{*}$ \\
JRE & $0.486^{* *}$ & NS & NS & $0.672^{* *}$ & NS & $0.411^{*}$ & $-0.528^{* *}$ \\
\hline
\end{tabular}

904 NS denotes "nonsignificant relationship". ${ }^{a} n=27$ for environmental variables and porewater $\mathrm{CO}_{2}$ concentrations

905 at shrimp ponds in each estuary. The symbols $*$ and $* *$ denote significant correlations at $p<0.05$ and 0.01 , 906 respectively. 
907 Table 3

908 Results of stepwise multiple linear regression analysis between $\mathrm{CO}_{2}$ production rates and various

909 environmental parameters in the overlying water of the Min River Estuary (MRE) and Jiulong

910 River Estuary (JRE).

\begin{tabular}{llllc}
\hline Estuary & Regression equations & $\boldsymbol{F}$-value & $\boldsymbol{R}^{2}$ & $\boldsymbol{p}$-value \\
MRE & $Y=3.949 X_{\mathrm{DOC}}-2.636 X_{\mathrm{pH}}-8.105$ & 38.161 & 0.761 & $<0.001$ \\
JRE & $Y=-1044 X_{\text {salinity }}+0.672 X_{\mathrm{DIC}}+10.373$ & 26.360 & 0.687 & $<0.001$ \\
\hline
\end{tabular}




\section{Table 4}

912 Results of stepwise multiple linear regression analysis between $\mathrm{CO}_{2}$ fluxes across the SWI and

913 various environmental parameters in the pond sediments of the Min River Estuary (MRE) and 914 Jiulong River Estuary (JRE).

\begin{tabular}{lllll}
\hline Estuary & Regression equations & $\boldsymbol{F}$-value & $\boldsymbol{R}^{\mathbf{2}}$ & $\boldsymbol{p}$-value \\
MRE & $Y=8.184 X_{\text {Temperature }}-0.502 X_{\mathrm{DIC}}+3.555 X_{\mathrm{TC}}-152.525$ & 15.006 & 0.662 & $<0.001$ \\
JRE & $Y=22.129 X_{\text {Temperature }}-546.524$ & 56.542 & 0.693 & $<0.001$ \\
\hline
\end{tabular}




\section{Table 5}

916 A summary of $\mathrm{CO}_{2}$ fluxes $\left(\mathrm{mg} \mathrm{m}^{-2} \mathrm{~h}^{-1}\right)$ across the sediment-water interface in different aquatic ecosystems (e.g. lakes, reservoirs, rivers, drainage ditch, aquaculture

917 ponds, and others).

\begin{tabular}{|c|c|c|c|c|}
\hline Ecosystems Type & Study Site & Average Depth (m) & Range & Reference \\
\hline \multirow[t]{4}{*}{ Lake } & Bled Lake, Slovenia & 17.9 & 9.2 & Ogrinc et al., 2002 \\
\hline & Stechlin Lake, Germany & 22.8 & $4.4-6.2$ & Casper et al., 2003 \\
\hline & Kevatön Lake, Finland & 2.3 & $20.2-56.8$ & Liikanen et al., 2002 \\
\hline & Baldeg Lake, Switzerland & $56-65$ & $3.9-13.2$ & Urban et al., 1997 \\
\hline \multirow[t]{4}{*}{ Reservoir } & Wilcza Wola Reservoir, Poland & 2.6 & $2.2-3.9$ & Gruca-Rokosz et al., 2011 \\
\hline & Solina Reservoir, Poland & 22.0 & $2.2-2.6$ & Gruca-Rokosz et al., 2011 \\
\hline & Rzeszów Reservoir, Poland & $0.5-6.0$ & $0.9-83.2$ & Gruca-Rokosz and Tomaszek, 2015 \\
\hline & Lobo Broa Reservoir, Brazil & 3.0 & $16.3-47.9$ & Adams, 2005 \\
\hline \multirow[t]{4}{*}{ River/Estuary } & Palmones River estuary & --- & $16.7-313.7$ & Claverol et al., 1997 \\
\hline & Mississippi River estuary & --- & $31.2-102.5$ & Morse and Rowe, 1999 \\
\hline & Kertinge Nor River estuary & --- & $128.5-155.8$ & Hansen and Kristensen, 1997 \\
\hline & Shanghai river network, China & $1.35-4.0$ & $-43.6-52.8$ & Tan et al., 2014 \\
\hline Intertidal mudflat & Nanakita River, Japan & --- & $117.0-533.7$ & Kikuchi, 1986 \\
\hline Drainage ditch & Netherlands & $0.25-0.90$ & $69.5-198.9$ & Schrier-Uijl et al., 2011 \\
\hline \multirow[t]{3}{*}{ Aquaculture pond } & Shandong Province, China & 1.8 & $19.8-124.1$ & Xiong et al., 2017 \\
\hline & Min River estuary, China & 1.3 & $43.6-97.7$ & Present study \\
\hline & Jiulong River estuary, China & 1.5 & $20.2-99.9$ & Present study \\
\hline
\end{tabular}

“---” indicated No data 
920 